\title{
Transboundary Water Conflict Resolution Mechanisms: Substitutes or Complements
}

\author{
Ahmed Tayia $\mathbb{D}$ \\ Centre for Environmental Policy (CEP), Imperial College London, London SW7 1NE, UK; \\ ahmed.tayia15@imperial.ac.uk; Tel.: +44-7493095757
}

Received: 21 May 2019; Accepted: 21 June 2019; Published: 28 June 2019

check for updates

\begin{abstract}
This paper examines the transboundary water resources conflict resolution mechanisms. Various academic fields have provided conflict resolution mechanisms that could be used to analyse transboundary water conflicts. These mechanisms include social planner, water market, game theory, static and dynamic systems engineering models, and negotiation analyses. These mechanisms share some common characteristic features. This similarity has led to a general belief that these mechanisms are competitive substitutes. However, closer examination by this research reveals that these mechanisms have more complementarity than similarity. This complementarity permits researchers and practitioners to combine any two or more of them to develop more comprehensive mechanisms with stronger analytical capacity to analyse the different elements of the process of transboundary water conflict resolution.
\end{abstract}

Keywords: transboundary water conflict resolution mechanism; hydro-diplomacy; systems engineering models; social planner; water market; game theory; hydropolitics and critical hydropolitics; hydro-hegemony; Transboundary Waters Interaction Nexus (TWINS); Alternative Dispute Resolution (ADR); virtual water

\section{Introduction}

Management of Transboundary water resources is expected be one of the biggest challenges facing human development over the next decades [1]. In general, transboundary water resources can describe water shared across political, economic, or social boundaries [2]. Shared water resources have been always a potential source of competition. The English language, as well as many other Latin-rooted languages, reflects this historical relation between shared rivers and competition, as it uses the word "rival" to refer to a competitor against others. The word "rival" is derived from the Latin word rivoalis, which refers to an individual using the same river stream as another and originated from the Latin word rivus meaning river stream [3]. At present, water scarcity and interdependence among water-sharing countries have created complex conflicts over shared water resources around the world. Moreover, these conflicts are expected to escalate as a result of the growing world population, industrial development, and increasing urbanisation, as well as the negative consequences of climate change [1]. This complexity and the increasing significance of water resources shared across political borders conflicts have attracted considerable research interest in many scientific fields during the past years. Thus, this article aims at reviewing this literature that addressed conflicts over water resources that are shared across political borders, which is henceforth referred to as transboundary water conflicts.

The literature regarding transboundary water resources conflicts has proposed various approaches for allocating transboundary water resources [4]. Engineering studies have focused on finding the optimal water allocation among parties sharing water resources [5]. Economic studies have attempted to identify the different economic options for allocating water optimally among conflictive countries [6]. 
Some of these studies have resorted to conventional economic approaches, such as "social planner" and "water market", to identify optimal water allocation [7]. A more comprehensive economic approach has been provided by game theory in the past two decades [8]. These game theoretic studies have linked the process of transboundary water conflict resolution to its outcome [8]. Political studies have addressed the political constraints that determine the dynamics and the outcome of transboundary water conflicts [9]. Finally, management studies have focused on the facilitation of the process of water conflict resolution [10]. Alternative Dispute Resolution (ADR) is one major approach that has been promoted by negotiations research [6]. However, the solutions that have been offered by the literature have not resulted in tangible actual practice of transboundary water conflict resolution [11].

The main objective of this study is to assess the gap between theory and practice in the field of transboundary water conflict resolution. More specifically, this research aims to identify why practitioners in actual transboundary water conflict resolution have not used the approaches that are offered by the academic literature. To achieve this, the research examines the approaches that have been suggested in the literature by four different academic fields, namely engineering, economics, political science, and management, as mechanisms of transboundary water conflict resolution. Subsequently, it identifies which of these mechanisms have been used in practice to solve transboundary water conflicts, in an attempt to assess the gap between theory and practice. Finally, based on this examination, the study identifies the reasons behind this gap and provides some recommendations to bridge the theory-practice gap in transboundary water conflict management.

This research provides an original contribution in its three key components: research theme, research scope, and its analytical framework. With regard to the research theme, it analyses the gap between the academic literature and real practices in the field of transboundary water conflict resolution. With regard to research scope, the research provides a multidisciplinary study that analyses academic literature on transboundary water conflict resolution originating from four different fields of inquiry, namely engineering, economics, political science, and management studies. Finally, the research introduces an analytical framework that offers a generic structure of water conflict resolution mechanism that can be used to assess the capacity of mechanisms either offered by academic literature or used by practitioners for transboundary water conflict resolution.

The study is divided to four sections, including this introductory section. The following section introduces the analytical framework that was used in this study. The third section explores these transboundary water conflict resolution mechanisms that are introduced by different scientific disciplines and its state of application. It then uses the analytical framework that was developed in this study to evaluate of the theoretical transboundary water conflict resolution mechanisms and the reasons behind the theory-practice gap. The final section discusses the findings of these study and provides some concluding remarks

\section{Analytical Framework and Method}

This section begins by exploring the different conceptualisations of conflict resolution that literature has proposed. Subsequently, these conceptualisations are used to delineate a functional structure for conflict resolution mechanism. This structure will be used as analytical framework to evaluate the theoretical mechanisms that have been used to analyse transboundary water conflicts.

\subsection{Conflict Resolution: Definition}

This section develops an operational definition for "Conflict resolution", which will be used in this study in four steps. First, the various perspectives of situations considered as conflicts will be discussed in order to establish a definition of conflict. Subsequently, the different conceptualisations of the conflict resolution process are presented, from which a working definition of conflict resolution will then be derived and used in this study.

Interest in studying conflict as a defined field grew in the second half of the twentieth century, although conflict as a general phenomenon has existed throughout human history. Fears of international 
conflict that were generated by the Cold War led scholars from different fields to study conflict, and, in particular, to identify the main defining characteristics of conflicts. The academic scholarship on conflict has been divided since then between two theoretical schools. The first school maintained the ancient conception of conflict as a physical confrontation [12]. This ancient conception was reflected in the Latin origin of the term conflict, conflīgo, which means to strike together [13]. Therefore, when Coser [14] introduced the concept of social conflict, he defined it as a struggle in which conflicting parties act to neutralise, wound, or eliminate their opponents. Similarly, Mack and Snyder [15] characterised conflict by the presence of behaviour aiming to hurt the other party. Deutsch [16] adopted a softer approach, perceiving conflict as a situation in which parties carry out, or attempt to carry out, incompatible activities. According to Bercovitch, Kremenyuk [12], the second school of thought perceives conflict as a psychological state of affairs. It broadens the scope of conflict to include conflict of goals, whether or not these goals are acted upon [17]. According to this school of thought, a situation is considered as a conflict when parties have incompatible desires and are mutually aware of this incompatibility [18]. Galtung [19] further develops the concept of conflict as a conflict of goals, introducing the concept of structural conflict to separate the periods before and after this incompatibility is recognised. According to him, a structural conflict exists among the parties when they have conflicting interests, whether they perceive this conflict of interest or not. This structural conflict would be latent until the parties perceive this incompatibility of goals. The structural conflict becomes a manifest conflict when the parties perceive the incompatibility.

Several conceptualisations of conflict resolution process have been presented in the literature. Some scholars prefer giving a broad meaning to conflict resolution process to include two stages: conflict settlement and conflict transformation. Conflict settlement refers to the achievement of a consensus among parties to settle their political conflict over the issue of conflict [17]. Conflict transformation implies a deep transformation in the deep-rooted sources of conflict to establish a more stable structure of relationships among the conflict parties [12].

Various scholars preferred to confine the term conflict resolution to conflict settlement stage, owing to the complexity of the conflict settlement stage. This study adopts this confined definition of conflict resolution. Conflict resolution is defined in this study as a process that aims to solve the central incompatibilities between conflict parties and create agreement among them on a solution for the conflict issues. This process is a multidimensional process that facilitates constructive social change among conflictive parties [20]. This multidimensional process is a macro-process that is composed of connecting micro-processes aiming at differences reconciliation and bargaining that usually occur during negotiations. These macro and micro conflict resolution processes may, or may not, include active involvement of a third party that can act as intermediary, arbitrator or even superior authority that can mandate a settlement.

\subsection{Conflict Resolution Mechanism: Structure}

Significant research in recent years has focused on developing comprehensive approaches to explain and influence complex social processes, such as conflicts and their resolution. In social sciences, as in science at large, three main competing perspectives of social processes explanation and prediction have generated considerable research interest. These perspectives are covering laws, scepticism, and mechanistic approaches.

On the one hand, the covering-law model entails that an explanation of an event implies subjecting it to a higher general law. A general law is a statement of universal causal form that works functions the same way under all [21]. This rule of universal application of general laws establishes structure equality between the explanation and prediction of events [22]. If a causal relation between event that has already occurred and particular initial conditions can be established, then the future occurrence of this event can be predicted if these initial settings exist at present. An explanation cannot be considered as complete unless it can function a prediction, according to this perspective [22]. Thus, in the covering laws, the causal relationship between the initial conditions and the terminal condition is deterministic. 
The difference between explanation and prediction using such a general law is the object of scientific enquiry. In explanation, the object of enquiry is the initial determining conditions of an existing or past event. In prediction, particular events are known to exist or to have happened, but there is a need for a projection of their future conditions. Thus, in this view, a general law is needed to connect an event, a terminal condition, to a group of events, initial conditions, with an invariant causal relationship.

On the other, a wide-spread sceptic view emphasises that any attempt to create universal law that is based on social events will fail. First, social events arise from actual sequence of events and particular connecting processes [23]. This complexity makes them singular events that cannot be subjected to general laws. Second, the difficulty of conducting controlled experiments excludes any possibility to uncover universal social law, if one exists. Therefore, this doctrine claims that social enquiry is mainly concerned with the description the experiences that led to particular events [21]. However, they stress that such descriptive accounts do not have any predictive power. Therefore, according to this perspective, there is a division between explanation and prediction, as social events are singular.

The third major approach to social analysis is the mechanistic approach, or simply mechanisms. A mechanism-based approach was developed as intermediate-level approach between general laws and descriptive accounts. Some scholars have proposed small-scale social processes to be the units of causal analysis, recognising the difficulty of analysing large-scale social events or processes in the framework of general covering rules [24]. Consequently, they introduced the concept of mechanism as a process-based approach that has explanatory and predictive power [25].

Various definitions of mechanisms have been proposed in the literature [23,26-34]. However, some characteristics are common among most of the accepted definitions. Two main characteristics of mechanism can be distinguished that not only define the nature of mechanisms, but also distinguish them from covering laws. First, covering laws analysis provides a black-box causal explanation between two events, while assuming that the causal link between them is devoid of structure. To the contrary, the structure of the link and its dynamic process are the main determinants of the terminal event. As Elster ([35], p. 49) explains, "going from a black-box regularity to mechanisms is to go from If $A$, then always $B$ to If $A$, then always $C, D$, and B". Second, having multiple mechanisms as explanatory options for any particular situation means that any particular mechanism is not absolutely true. It can be true in particular instances while being untrue in others. Again, as Elster ([35], p. 49) clarifies, "the move from theory to mechanism is from If A, then always B to If A, then sometimes B". Therefore, the problem in any particular situation is to determine which mechanism has been followed, or can be applied, in this case [36].

The term mechanism is used in this study to refer to a scientific representation of a social process that produces a particular set of changes from initial conditions to terminal conditions in the light of all indicated above. The agents and activities involved in this process and their organisation, as well as the environment that constrains the process determine the process dynamics, operation, and outcome. This environment includes all physical, legal, psychological, economic, political, and social constraints of the process.

Consequently, a conflict resolution mechanism is defined as a scientific representation of a conflict resolution process, delineating the conflict parties, their activities in this process, the initial and terminal conditions of the process, and the conflict environment for the purpose of this study. The initial conditions refer to the state of the issues that represent the substance of the conflict among parties at the beginning of the conflict. Terminal conditions refer to the state of these conflict issues at the end of conflict resolution process. The conflict environment includes all physical, legal, psychological, economic, political, and social factors that influence the conflict resolution process. Figure 1 delineates the structure of conflict resolution mechanisms. 

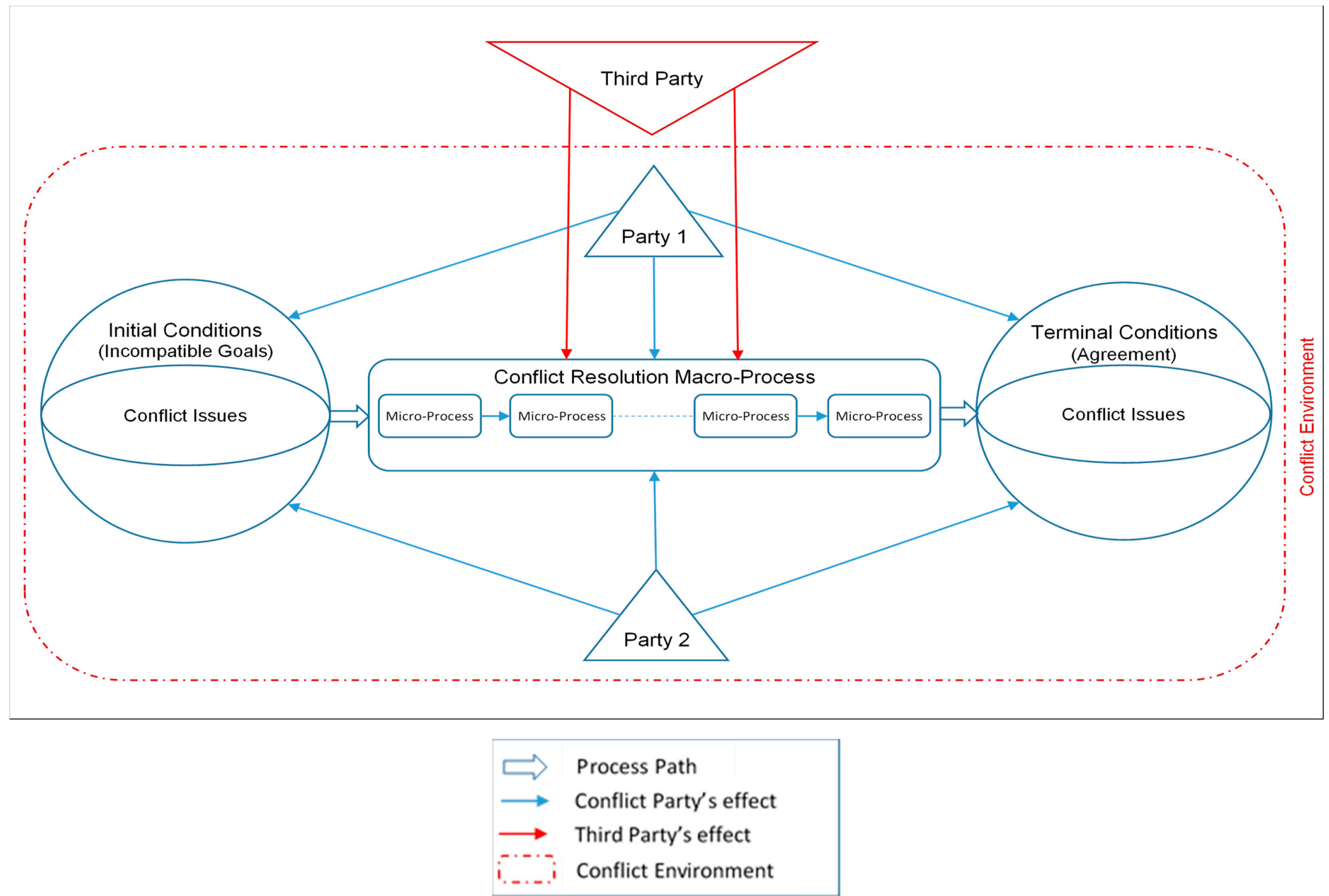

Figure 1. Conflict Resolution Mechanism Structure Used in the Study as Analytical Framework. 
If a conflict resolution mechanism is used for explanatory purpose, it is referred to a positive or descriptive mechanism. In this case, its main objective would be to explain the process structure and dynamics that led from the given initial conditions the terminal conditions. On the other hand, if the mechanism is used for prediction and planning, it is referred to as a normative or prescriptive mechanism. Predicative mechanisms can be categorised into two types. In the first type, the initial conditions and the process structure and parties' activities are given, while the terminal conditions are to be predicted. In the second, the initial conditions and the terminal conditions are given, while the process structure and parties' activities are to be predicted. However, in reality, it is very common that analysts only have the current status identified, but not the optimal process or the optimal terminal conditions. It becomes their task to identify the optimal outcome and the optimal negotiations process to achieve that outcome. This conflict resolution mechanism structure is used in this study as thee analytical framework to examine the explanatory and predictive power of the theoretical water conflict resolution mechanisms presented in the literature.

\section{Analysis}

This part explores the various theoretical approaches that have been used to analyse transboundary water conflicts and their possible mechanisms of resolution. It begins by delineating the main feature of transboundary water disputes that affect its process of settlement. Subsequently, it analyses the approaches that were proposed by the various academic disciplines to transboundary water conflict resolution. This analysis includes a review of the main studies that used each of these approaches, followed by their state of application by practitioners in reality.

The transboundary water conflicts are usually contentious, as it usually includes various conflicted issues. In general, the complexity of conflict structure is significantly determined by the range of disputed issues in conflict. Issues become a substance of conflict when they are scarce [15]. A conflict may erupt as a result of competition over various types of scarce resources, such as status, power, position, and natural resources [37]. In general, conflict issues could be grouped into five basic types: natural resources; sovereignty; survival; honour; and, ideology [38]. The transboundary water resources are surface water and ground water resources that cut cross political borders of states. Therefore, transboundary water conflicts are usually contentious, because it crosses three overlapping issues: natural resources, survival, and sovereignty. Moreover, transboundary water resources are subject to multiple physical and social constraints that regulate transboundary water. These constraints are enrooted in various disciplines that include hydrology, international relations, international law, economics, engineering, and climate science, among others. Therefore, the resolution of transboundary water conflicts needs sophisticated efforts, because of the multiplicity of conflict constraints.

Literature has developed various mechanisms for dealing transboundary water conflict resolution over the past decades. These mechanisms are rooted in three main disciplines: Engineering, Economics, Political Science and Management studies. Engineering-based approaches have mainly relied on models as a mechanism for water management and conflict resolution. Scholars who analysed the economic dimension of transboundary water disputes introduced the "social planner" mechanism and the "water market" mechanism. A more comprehensive economic mechanism has been provided by game theory that has brought together the economic and political dimensions of the water dispute management. The political perspective introduced two main theoretical lines, hydropolitics and critical hydropolitics, which analyse the political constraints on transboundary water conflict resolution. Finally, other approaches, such the Alternative Dispute Resolution (ADR), have focused on the negotiation process.

\subsection{Engineering Approaches}

Early attempts to address water management problem relied on conventional sectorial approaches. Gradually, attempts have been made to use more comprehensive approaches to address the complexities of water resources management. Two main paradigms have dominated the water resources management during the past few decades: the uncertainty paradigm and the complexity paradigms [39]. The 
uncertainty paradigm focuses on the availability of water related data and its variability. The complexity paradigm deals with the complexity of water resources planning and management.

This systems approach perceives water resources management as a complex process that should take the social, economic, political, and environmental dimensions into consideration. Scholars developed mathematical models of water resources as mechanisms to efficiently analyse water basins to evaluate these dimensions [5]. The increasing complexity of water, the rapid increase in computer processing power, and the growing ease of use of modelling tools have given rise to a solid and comprehensive approach for water resources management, which is referred to as systems analysis. Systems models that are used to analyse transboundary water conflicts can classified into two categories: static models and dynamic models [5]. The static models are used to examine the impact of change in the initial conditions on the terminal conditions of conflict. Dynamic models analyse the evolution of the conflict resolution process over time due to a change in the initial conditions and they try to predict the terminal conditions of the conflict resolution process.

\subsubsection{Static Models}

Since the 1960s, various studies have attempted to analyse water resources in the framework of systems analytical concepts. These studies mapped water resources as a set of various components or subsystems that interact in a logical manner [40]. The interconnections of the subsystems impose constraints upon each other, thus limiting the range within which the individual inputs could be assigned. Consequently, scholars redefined the water systems elements and interactions by means of mathematical or logical functions. These mathematical models have been used to find the combination of components and interactions that satisfy a desired objective or achieve optimal output. In other words, the systems approach has been mainly concerned with prediction and control. Engineering mechanisms can be positive or normative, similar to economic mechanisms. However, engineering models have focused on prediction and planning was extended to the conflict resolution field.

Transboundary water conflict resolution are multi-criteria multi-participant problems. Conventional optimisation models have aggregated the multiple participants into a single decision-maker then attempt to identify the Pareto-based optimality for such a water system. Other systems engineering mechanisms attempted to achieve sub-optimal (Pareto-inefficient) settlements that could be perceived fair by parties, and hence accepted by them [41]. These mechanisms have included least square analysis, goal programming, and compromise programming. The least square analysis method proposes the water allocation scheme that minimises the aggregate dissatisfaction of parties by minimising the squared differences between the parties' desired shares and the proposed resource shares. The goal programming methods select a scheme allocating water among parties in a way that either guarantees the minimum dissatisfaction level for the most dissatisfied party (Minimax) or guarantees the maximum satisfaction level for the least satisfied party (Maxmini). Compromise programming provides a solution that minimises the distance between and the desired solution for the ideal allocation scheme.

Various studies employed these systems mechanisms to address water resources conflict while using optimisation techniques as conflict resolution mechanisms. The Danube River, the Nile Basin, Ganges River Basin, Caspian Sea, and Nestos River have been analysed while using different optimisation techniques, including multi-objective multi-participant optimisation, linear programming, and dynamic programming (Table 1). Almost all of these studies were conducted with the aim of providing policy advice and there is no evidence of having been used by decision makers. These optimisation methods implicitly reduce economic actors into a single decision maker with a composite objective, such as social welfare function, and then attempt to optimise such a composite objective. The weakness of these technique is that it assumes perfect cooperation among the actors or the existence of a social planner, which is an assumption that is far from being realistic. These techniques focused on identifying the possible conflict settlement, i.e., the terminal conditions, under ideal conditions, while it ignored the dynamic resolution process and the environmental constraints (Figure 2). 
Table 1. Static Models-Theory and Implementation.

\begin{tabular}{|c|c|c|c|}
\hline \multicolumn{4}{|c|}{ Optimisation } \\
\hline $\begin{array}{l}\text { Problem } \\
\text { Addressed }\end{array}$ & Issue Addressed & Objective & Citation \\
\hline Danube River & $\begin{array}{c}\text { Applying compromise programming, as a multi-criteria } \\
\text { multi-actor decision technique, to assist in conflict resolution } \\
\text { among riparian countries }\end{array}$ & $\begin{array}{l}\text { Prediction } \\
\text { Planning }\end{array}$ & [42] \\
\hline \multirow{2}{*}{ Nile River Basin } & $\begin{array}{l}\text { Using the cybernetic paradigm to study the policy options for } \\
\text { development of Egypt and Ethiopia between } 2000 \text { and } 2050 \text { s as } \\
\text { constrained by the shared finite water resources of the Nile }\end{array}$ & $\begin{array}{l}\text { Prediction } \\
\text { Planning }\end{array}$ & [43] \\
\hline & $\begin{array}{l}\text { Using multi-criteria optimisation approach to identify the best } \\
\text { performing reservoir designs that balance between the water } \\
\text { allocations and uses by the Eastern Nile countries. }\end{array}$ & $\begin{array}{l}\text { Prediction } \\
\text { Planning }\end{array}$ & [44] \\
\hline Ganges River Basin & $\begin{array}{c}\text { Combining linear programming and game theory to analyse the } \\
\text { alternatives for manage the river }\end{array}$ & $\begin{array}{l}\text { Prediction } \\
\text { Planning }\end{array}$ & [45] \\
\hline Aral Sea & $\begin{array}{l}\text { Modelling and evaluating different future scenarios for the Aral } \\
\text { Sea basin countries }\end{array}$ & $\begin{array}{l}\text { Prediction } \\
\text { Planning }\end{array}$ & {$[46,47]$} \\
\hline Nestos/Mesta River & $\begin{array}{l}\text { Using multi-criteria decision analysis as a tool for conflict } \\
\text { resolution in Nestos/Mesta River shared by Greece and Bulgaria } \\
\text { in South Eastern Europe. }\end{array}$ & $\begin{array}{l}\text { Prediction } \\
\text { Planning }\end{array}$ & [48] \\
\hline Caspian Sea & $\begin{array}{l}\text { Using Multi-Criteria Decision making methods to Evaluate the } \\
\text { different options for sharing the Caspian Sea and allocating the oil } \\
\text { and natural gas resources to parties. }\end{array}$ & $\begin{array}{l}\text { Prediction } \\
\text { Planning }\end{array}$ & [49] \\
\hline
\end{tabular}

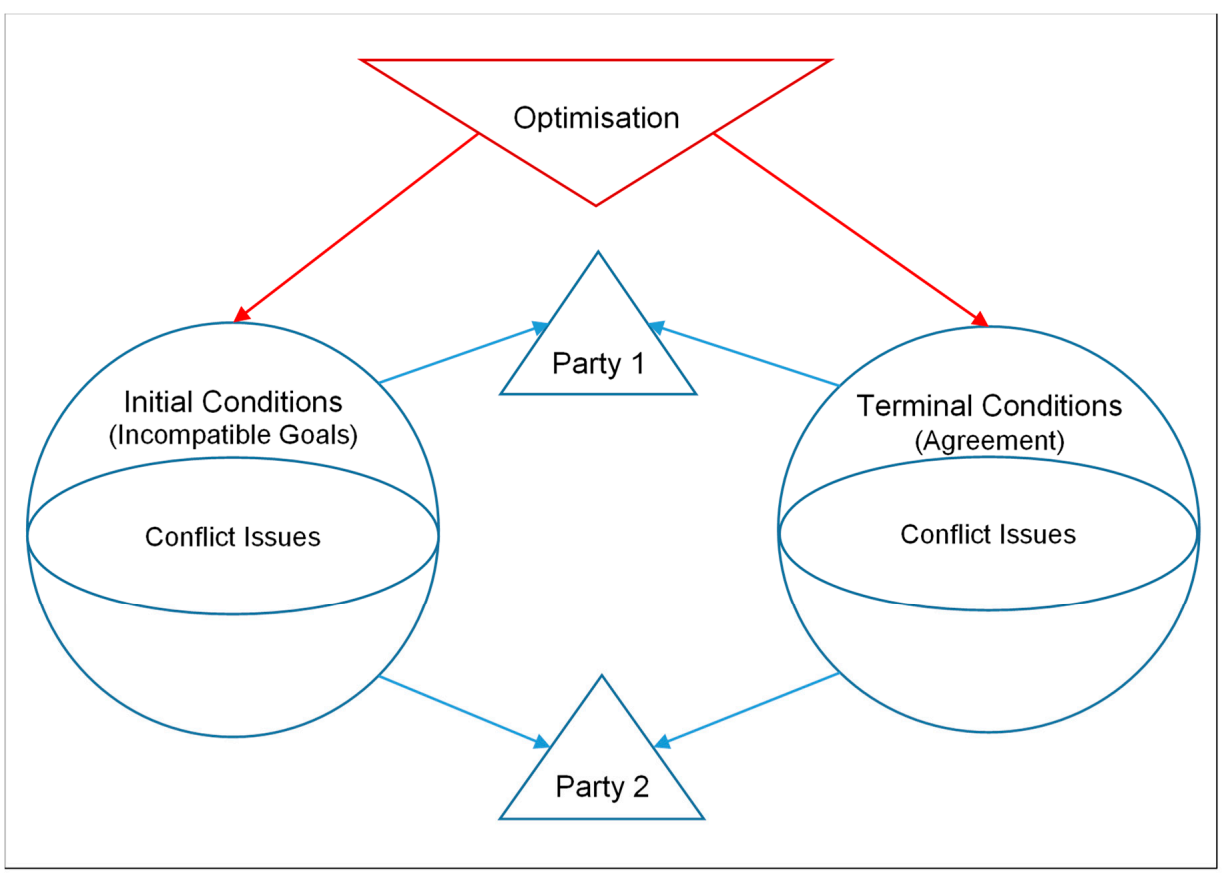

Figure 2. Structure of Optimization Modelling Mechanism.

\subsubsection{Simulation Models}

One of the main challenges that face transboundary water conflict resolution is the need to analyse a vast amount of physical and social data. This analysis is necessary for evaluating the available alternatives during the negotiations process. Optimisation models have been mainly used to analyses the milestones of the conflict resolution process, providing alternatives for decision making at these decision nodes. However, there has been a need for tools that can analyse dynamic changes during the conflict resolution process rather than snapshots of it. 
Therefore, another type of the engineering models that relied on the gigantic computer processing power. One variant of these models attempted to simulate transboundary water management under different conditions to provide the possible future scenarios of conflictive water resources. A good example of these studies is the one that was conducted by Siegfried and Kinzelbach [50] to analyse the future of the transboundary northwest Sahara aquifer. The Conflict Resolution Support System (CRSS) is a similar simulation modelling tool that was developed by Rajasekaram, Simonovic [51] to implementation of a systemic approach to help parties in water conflicts. However, although such types of models succeeded in providing a prediction of the evolution conflicted water resources management process under different initial conditions; it failed to account for the continuous changes that occur during this evolution process as a result of external or internal forces. Moreover, these models focus on modelling the process initial and terminal conditions and give less attention to the agents' preferences and decisions.

These continuous changes were internalised by another computer-based systems approach, which is known as system dynamics that was developed during 1960s. System dynamics provide a strong analysis platform that can map the interrelationships between the physical systems and social systems [52]. These relationships are captured using the feedback linkages among the different parts of the system. The system dynamic relationships can be mapped while using mental models in the form of causal loop diagrams or formally modelled while using computer-based simulation tools. System dynamics has provided a powerful tool for analysing water management and conflicts within the national boundaries [53-57]. However, it has lacked a clear conceptualisation of the parties that are involved in the conflict. Most system dynamics models assumed full collaborative conflict resolution process, which again assume full cooperation among the parties. This assumption reduces the conflict resolution process from a multi-objective multi-agent process to a multi-objective process (Figure 3). Such reduction limited the explanatory and the explanatory power of these models on the case of transboundary water conflicts. Some recent studies attempted to include the conflicting parties through representing their utility functions [52,55]. These studies pave the way for a wider application of system dynamics in the field of transboundary water conflict resolution (Table 2).

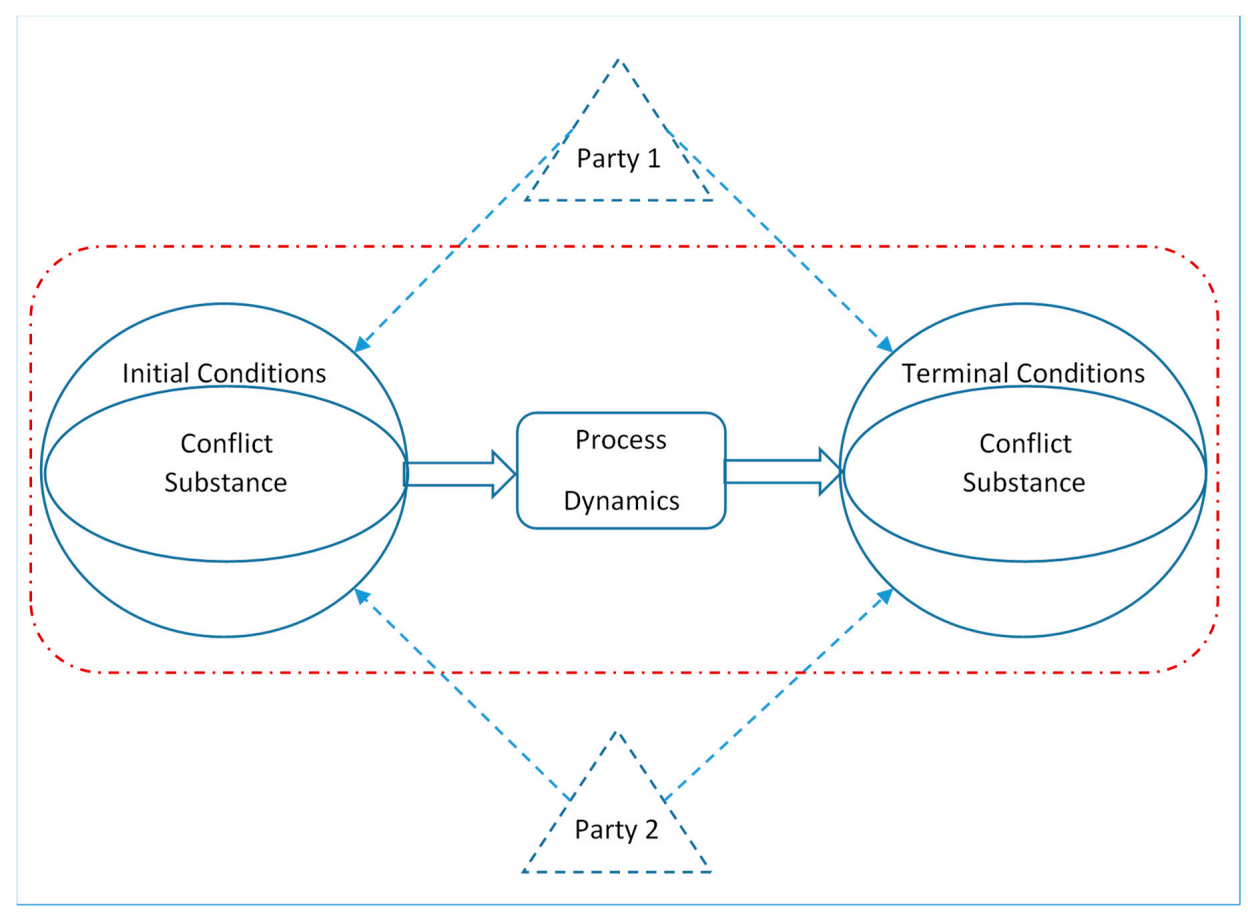

Figure 3. Structure of Simulation Modelling Mechanism. 
Table 2. Simulation Models-Theory and Implementation.

\begin{tabular}{|c|c|c|c|}
\hline \multicolumn{4}{|c|}{ Simulation Models } \\
\hline $\begin{array}{l}\text { Problem } \\
\text { Addressed }\end{array}$ & Issue Addressed & Objective & Citation \\
\hline $\begin{array}{l}\text { Northwest Sahara } \\
\text { aquifer }\end{array}$ & $\begin{array}{c}\text { Developing a simulation model using a multi-objective discrete } \\
\text { stochastic optimization approach to identify capital gains that can } \\
\text { be achieved by the establishment of intelligent pump scheduling } \\
\text { by Algeria, Tunisia and Libya. }\end{array}$ & $\begin{array}{l}\text { Prediction } \\
\text { Planning }\end{array}$ & [50] \\
\hline Nile River Basin & $\begin{array}{l}\text { Developing a system dynamics model that simulate the impact of } \\
\text { climate change and population growth on the water adequacy of } \\
\text { riparian countries and on the possibility of eruption of } \\
\text { intra-regional conflict }\end{array}$ & $\begin{array}{l}\text { Prediction } \\
\text { Planning }\end{array}$ & {$[58,59]$} \\
\hline $\begin{array}{l}\text { Hirmand } \\
\text { Transboundary } \\
\text { River Basin }\end{array}$ & $\begin{array}{l}\text { Adopting system dynamic approach to map the causal } \\
\text { relationships of Hirmand transboundary river system shared } \\
\text { between Iran and Afghanistan to guide the development planning } \\
\text { across the region }\end{array}$ & $\begin{array}{l}\text { Prediction } \\
\text { Planning }\end{array}$ & [60] \\
\hline $\begin{array}{l}\text { Hypothetical Water } \\
\text { Resource System }\end{array}$ & $\begin{array}{l}\text { Developing a system dynamics model assist parties with two } \\
\text { different jurisdictions to resolve a potential water-sharing conflict. }\end{array}$ & $\begin{array}{l}\text { Prediction } \\
\text { Planning }\end{array}$ & {$[45,52]$} \\
\hline
\end{tabular}

\subsection{Economic Analysis}

Long-term sufficiency of natural resources has been a major concern for economists since the emergence of economics. This concern has risen, because many of these natural resources can diminish either because they are non-renewable or because its renewable supply is not enough to meet the growing demand [61]. Since human survival relies on these natural resources, its scarcity has been a major concern for early economists. Malthus expressed the concern over the declining sufficiency of natural resources of living natural resources [62], who perceived population growth as the major source of pressure on food supply. He stressed that "the power of population is indefinitely greater than the power in the earth to produce subsistence for man" ([62], p. 4). The interest on non-living natural resources can be traced back to the analysis of Jevons [63] of the impact of the exhaustion of coal mines in Britain in regards to British economic growth.

Like the other theoretical schools, the economic analysis of conflicts over natural resources, including water resources, has addressed the two main concerns that are related to conflicts: explanation and prediction. Historically, the first concern of economic research has been explaining the causes of conflicts. However, the Cold War generated considerable research interest in studying the future of conflicts and providing possible solutions for conflict resolution. Even though the orthodox economic schools of thought have agreed on the explanation of the causes of conflicts in the framework of common-pool resources; however, these schools have differed regarding its resolution.

The economic explanation of natural resources conflicts is rooted in the behavioural conception of the classical economic thinking, which crafted economics as a new field of social analysis. This behavioural conception has been adopted, but with adaption, by the economic streams that inherited the orthodox tradition of economic analysis, notably, Keynesian, neo-classical, Institutional schools of thought. This conception has three main assumptions: the scarcity of resources, utility-based motivation, and the capacity of rational choice.

Economics aimed to study the allocation of scarce resources among different uses since its early development. Resources have been interpreted as objects, which can directly or indirectly satisfy human desires. This scarcity implies competition over them, and hence actors in an economy need to evaluate their available options and make choices that best serves their interests [64]. This logic has raised two questions to be answered by economic scholars. The first has been how economic actor evaluate their alternative option and how they make their choices from these alternative options.

The judgment of what economic actors evaluate their alternative options depends on the value system that was adopted in economic analysis. Much of the classical economic perspective relies on utilitarianism as its normative standard [61]. Utility is perceived as "that principle which approves or 
disapproves of every action whatsoever, according to the tendency it appears to have to augment or diminish the happiness of the party whose interest is in question" [65]. According to this academic tradition, "utility, or the Greatest Happiness Principle, holds that actions are right in proportion as they tend to promote happiness, wrong as they tend to produce the reverse of happiness" [66]. Moreover, this utilitarian conception evaluates the morality of the actions is only determined by its consequences and by its motives [66]. Thus, this conception has been called instrumental utility. Jevons [67] has argued that pleasures and pains can be represented by positive and negative algebraic quantities that represent utility and disutility, respectively. "The algebraic sum of a series of pleasures and pains will be obtained by adding the pleasures together and the pains together, and then striking the balance by subtracting the smaller amount from the greater. Our object will always be to maximise the resulting sum in the direction of pleasure" [67]. Jevons emphasised the need to estimate the physical objects that induce such feelings, recognising the difficulty of measuring feelings. Therefore, he introduced the term "commodity" as an indicator of actors" feelings. He defined commodity as "any object, substance, action, or service, which can afford pleasure or ward off pain" [67]. Accordingly, he defined utility as "the abstract quality whereby an object serves our purposes" [67]. Finally, he concluded by arguing that any commodity that can induce pleasure or prevent pain has utility [67]. The sum utility of a commodity is the sum of its positive utilities with negative dis-utilities to an actor. Moreover, social utility can be assessed by evaluating the sum total of individual utilities of all members of the society [61].

Nineteenth-century utilitarian conception, which focused on happiness as the motive behind human actions, influenced classical conception of rationality. Therefore, the role of reason in forming rational behaviour was limited to the means and not the goals. In other words, the rationality of behaviour was not seen as the rationality of goals, but the rationality of means to achieve these ends. Therefore, the behaviour of an actor can be judged as rational when he adopts, or intends to adopt, suitable means to achieve his ends. Moreover, altruistic motives were excluded from actors' motives. The goal of an actor should be to increase his own happiness. Adam Smith, one of the founders of the economic science, [68] stressed that agents are not motivated by humanity, but by "self-love". Similarly, Francis Edgeworth stated explicitly that "the first principle of Economics is that every agent is actuated only by self-interest" [69]. Therefore, the assumption behind rationality has been reinterpreted as the adoption of actor of suitable means to maximise his own utility. Implicitly, this hypothesis of rationality assumes that an agent has unlimited capacity to understand his environment has unlimited computational powers [70].

The market has to meet four conditions in order to efficiently allocate resources, assuming the rationality of economic agents: perfect information is available for all economic agents; perfect competition; full mobility of resources; and finally, ownership rights over resources, goods, and services are clearly defined [71]. The market reaches equilibrium when the quantity demanded equals the quantity supplied [72]. Economic theory has shown that, in this perfectly competitive market, no producer can be better off without at least one buyer being worse off [73]. In other words, the sum total of the net benefit of producers and consumers is maximised [73]. This conclusion implies economic efficiency at equilibrium, which has been referred to as Pareto optimality [73]. However, in the case of shared natural resources, the market may fail to reach such equilibrium because of lack of definition of property rights to such common-pool resource, such as transboundary water resources. This problem of common-pool resources started to attract research interest since the beginning of the 20th Century. Pigou [74] and Gordon [75] provided two lines of analyses of the problem of common-pool resources that paved the way for the introduction of two main mechanisms to solve this problem. The first mechanism is called social planner, which is enrooted on the Keynesian interventionist line of thinking. The other mechanism is water market, which was introduced by neo-classical economists. 


\subsubsection{Social Planner}

Arthur Pigou [74] analysed the divergence between the private and social net benefit of a product or an action, a phenomenon that became later known as externality. Externality refers to an economic condition in which a cost was incurred or a benefit accrued to a party who does not commit an action that results in that cost or benefit [76]. More specifically, externality is present when the utility of an affected individual is influenced by a vector of activities under his or her own control, but also affected by one or more activities under the control of another party, or parties, who belong to the same social group [76,77]. In this case, social benefit, as measured by social utility, diverges from private benefit measured by individual utility. Positive externality arises from a divergence between private and social benefit, whereas negative externality arises from a divergence between private and social cost. Pigou's analysis [74] served two purposes: firstly, it showed the impact of the divergence between social and private benefits or costs on the efficiency of the market; secondly, it proposed the intervention of central authority to correct this market failure with such a situation. Several policy options, which became known as commend-and-control policies, but all of them shared a common feature, which is having a central authority that is in charge of planning and implementation. This analysis of externalities was extended to shared water resources, which led to the introduction of what has become known social planner mechanism.

A social planner mechanism assumes a hypothetical benevolent decision maker whose objective is to maximise the overall economic welfare of the water basin. Generally, this allocation is called social or Pareto optimal allocation when resources are allocated in a way that it is impossible to make any one individual better off without making at least one individual worse off. A social planner would allocate based on overall efficiency of water use in the basin, regardless of the individual interests of water sharing parties to achieve a Pareto optimal allocation. For example, in a transboundary river basin, a social planner establishes social welfare function by assigning weights for riparian countries based on their efficiency. Consequently, water is allocated among riparian countries based on these social welfare weights. This implementation of water allocation yields the highest basin welfare, and is hence considered to be a social optimal allocation. It is worth mentioning that some studies recently used social choice theory to apply some social choice procedures to provide potential solutions for transboundary water conflicts [78]. Some of these potential solutions provide less-then optimal solution to achieve the necessary consensus among parties and the stability of post-conflict arrangements [41].

Although researchers have extensively used this mechanism as a planning tool, its application has been limited in reality. On the academic level, various studies have used the social planner mechanism to address transboundary water management (see Table 3). In rare cases, the social planner was used as an explanation mechanism, such as the analysis of the Columbia River Treaty of 1964 by Krutilla [79]. The mechanism was extensively used as a prediction and planning tool to address conflictive management and planning issues in various transboundary water basins, such as the Columbia River basin, the Nile River Basin, Ganges-Brahmaputra River Basin, Great Lakes between the United States and Canada, and the Caspian Sea. However, in practice, academic efforts were only partially translated into policy actions in two cases (see Table 3). The first case was the development plan of the Nile Basin in the first half of the Twentieth Century. The United Kingdom, which was the major colonial power in the basin at that time, commissioned its experts to conduct a series of studies to maximise the utilisation of the Nile water, mainly in agriculture to provide its textile industry with the necessary cotton supplies. These results of these studies were partially implemented through a series of treaties and projects in the first half of the past century. The second case was a plan that was developed by a joint governmental committee between the United States and Canada to solve the pending water question between the two countries over the Columbia River. This plan was materialised in the agreement signed between the two countries in 1964. 
Table 3. Social Planner Mechanism-Theory and Implementation.

\begin{tabular}{|c|c|c|c|c|}
\hline \multicolumn{5}{|c|}{ Social Planner (Central Planning) } \\
\hline Problem Addressed & Issue Addressed & Objective & Implementation & Citation \\
\hline \multirow[t]{2}{*}{ Columbia River Basin } & $\begin{array}{l}\text { Developing a plan for the upper Columbia Basin } \\
\text { prepared by the International Joint Commission (IJC) } \\
\text { established by the Boundary Waters and Questions } \\
\text { Arising Between the United States and Canada. }\end{array}$ & $\begin{array}{l}\text { Prediction } \\
\text { Planning }\end{array}$ & \multirow[t]{2}{*}{$\begin{array}{l}\text { The Columbia } \\
\text { River Treaty of } 1964\end{array}$} & [80] \\
\hline & $\begin{array}{l}\text { Explaining the development, The Columbia River Treaty } \\
\text { of } 1964 \text { and evaluating its economic benefits. }\end{array}$ & $\begin{array}{l}\text { Explanation } \\
\text { Analysis }\end{array}$ & & [79] \\
\hline \multirow{4}{*}{ Nile River Basin } & $\begin{array}{l}\text { Developing a comprehensive framework for the Nile } \\
\text { control projects in Nile Basin to increases Egypt's and } \\
\text { Sudan's annual water shares. }\end{array}$ & $\begin{array}{l}\text { Prediction } \\
\text { Planning }\end{array}$ & \multirow{2}{*}{$\begin{array}{c}\text { The Nile Water } \\
\text { Treaty of } 1929 \\
- \\
\text { Treaty of Owen } \\
\text { Dam of } 1949\end{array}$} & $\begin{array}{c}81] \\
{[82,83]} \\
{[84]} \\
{[85]} \\
{[86]}\end{array}$ \\
\hline & $\begin{array}{l}\text { Analysing of the development of treaties of } 1929 \text { and } \\
\qquad 1949\end{array}$ & $\begin{array}{l}\text { Explanation } \\
\text { Analysis }\end{array}$ & & $\begin{array}{l}{[87]} \\
{[88]}\end{array}$ \\
\hline & $\begin{array}{l}\text { Providing Preliminary proposals for increasing the } \\
\text { utilizable annual water supply of the Nile. }\end{array}$ & $\begin{array}{l}\text { Prediction } \\
\text { Planning }\end{array}$ & & [89] \\
\hline & $\begin{array}{l}\text { Evaluating the economic benefits of cooperation among } \\
\text { riparian countries. }\end{array}$ & $\begin{array}{l}\text { Prediction } \\
\text { Planning }\end{array}$ & & {$[90]$} \\
\hline $\begin{array}{l}\text { Ganges-Brahmaputra } \\
\text { River Basin }\end{array}$ & $\begin{array}{l}\text { Analysing the alternatives for water transfer from } \\
\text { Brahmaputra River to Ganges River }\end{array}$ & $\begin{array}{l}\text { Prediction } \\
\text { Planning }\end{array}$ & & {$[91]$} \\
\hline Caspian Sea & $\begin{array}{l}\text { Using Multi-Criteria Decision making methods and } \\
\text { social choice procedures to Evaluate the different options } \\
\text { for sharing the Caspian Sea. }\end{array}$ & $\begin{array}{l}\text { Prediction } \\
\text { Planning }\end{array}$ & & {$[41,49,78]$} \\
\hline $\begin{array}{l}\text { Great Lakes } \\
\text { USA and Canada }\end{array}$ & $\begin{array}{l}\text { Comparing social planner with non-cooperative game } \\
\text { solutions to the problem of water diversion from the } \\
\text { lake. }\end{array}$ & $\begin{array}{l}\text { Prediction } \\
\text { Planning }\end{array}$ & & [93] \\
\hline
\end{tabular}

The main strength of this mechanism is the fact it provides the most efficient yield for the whole group of conflicting parties. However, it faces two key challenges, which limits its application as a mechanism resolving real conflicts. First, it assumes the possibility of establishing a water management system based on a basin-wide objective function, ignoring the difference in preferences, with its political, economic, and cultural determinants, among the riparian countries [6]. In other words, it ignores the conflict environment and its constraints. Second, its assumption of the existence of some central decision making ignores the sovereignty of parties in transboundary water conflicts. It assumes a passive attitude of parties, with full obedience and commitment to the decision of the central planning entity. Thus, this mechanism replaces the process of conflict resolution by a single decision maker (Figure 4). These dynamics include the parties' interests, strategies, and actions during the process of conflict resolution. The social planner mechanism has been reduced to water allocation criteria by excluding the conflict resolution process. This reduction limited its full application in reality. However, it still provides a benchmark outcome that can guide parties during their negotiation process. 


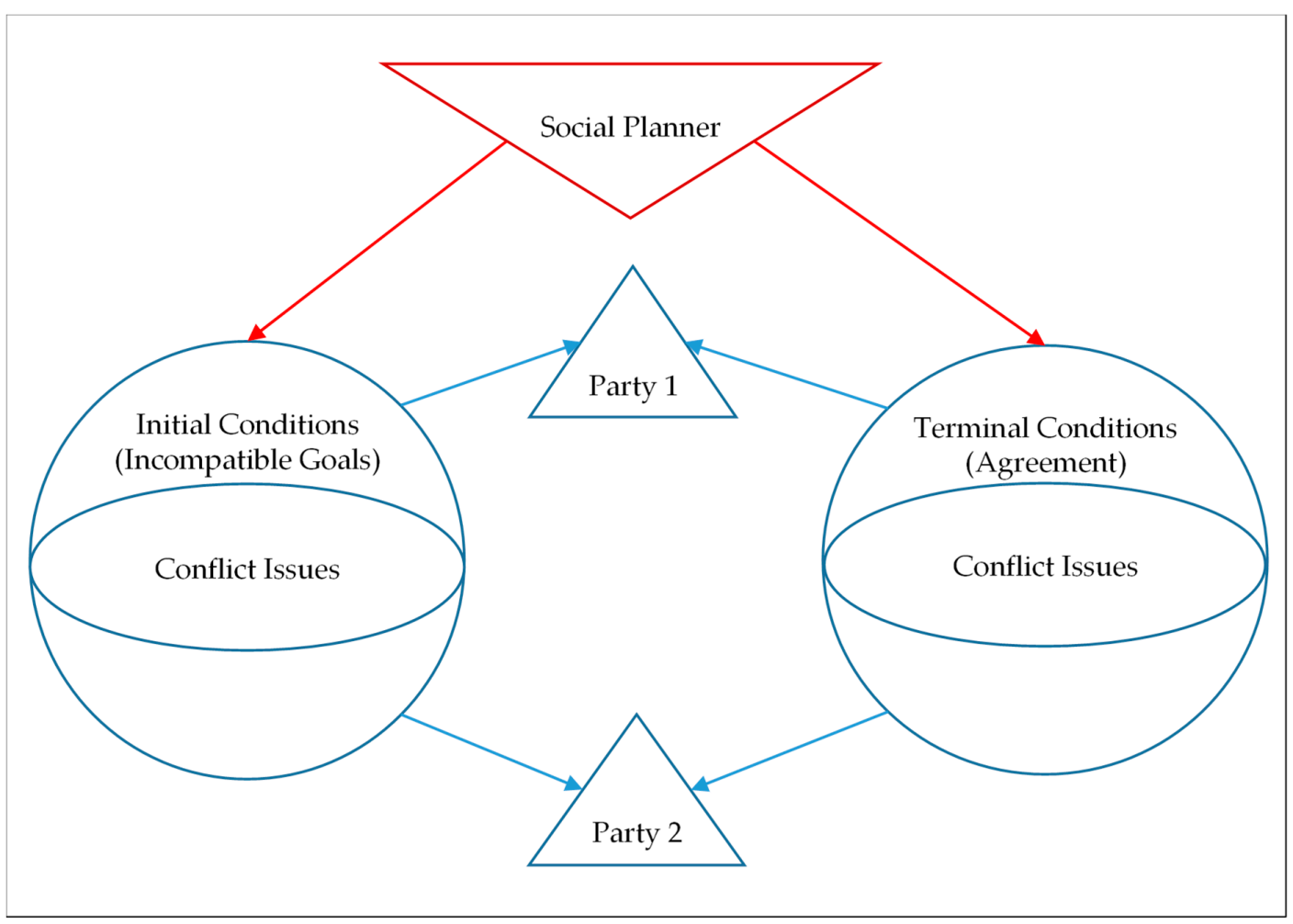

Figure 4. Structure of Social Planner Mechanism.

\subsubsection{Water Markets}

Gordon provided an extensive analysis of shared natural resources in the 1950s [75]. He analysed the case of fisheries as a representative model for common-pool resources to show the problems that result from the competition over shared natural resources. Gordon's model shows that open-access common resources give rise to a pattern of competition among appropriators that leads to an inefficient outcome. Hardin [94] developed this idea by demonstrating that such an outcome is not only economically inefficient, but also physically inefficient and unsustainable. He coined the term "tragedy of commons" to describe the competition over common natural resource, clarifying that in such situations "each man is locked into a system that compels him to increase his herd without limit-in a world that is limited. Ruin is the destination toward which all men rush, each pursuing his own best interest in a society believes in the freedom in the commons" [94].

This analysis common-pool resources alarmed economists to the importance of establishing a clear structure of appropriation rights to natural resources that can support an efficient allocation of shared resources. Coase [95] adopted this approach, who emphasised that given a well-defined structure of property rights, a costless transferable and enforced exchange will eliminate all externalities and the resource allocation will not be determined by the pattern of the assignment of property rights [95]. This idea of using the market mechanism to manage resource appropriation rights of common-pool resources was extended to water resources management, which resulted in the introduction of what has been known as water market.

Therefore, water economists have argued that a market could represent an efficient mechanism for water rights allocation. The market mechanism that has been proposed is allocate-and-trade, which is a market mechanism that relies on two-step procedure [96]. The first step is establishing an initial allocation of water rights among the water-sharing countries. The second step would be auctioning the water surplus of the potential supply countries to the potential demand countries. This auction can take the either of two forms: a percentage-claim auction or priority-claim auction [7,97]. In percentage-claim auctions, potential demand countries bid for a share of an uncertain water surplus from potential 
supply countries. In priority-claim auctions, potential demands countries bid for a slot in a queue for the water surplus of possible supply countries. This last form of auction can be conducted as one-stage auction or as a multi-stage auction to allow the bidder to increase their bids [98]. Although various studies have used this mechanism to propose efficient allocation of water in various basin or region, such as the Nile Basin, Middle East Region, and Ganges River Basin, no evidence that any of these studies has been materialised (see Table 4).

Table 4. Market Mechanism-Theory and Implementation.

\begin{tabular}{|c|c|c|c|}
\hline \multicolumn{4}{|c|}{ Water Markets } \\
\hline $\begin{array}{l}\text { Problem } \\
\text { Addressed }\end{array}$ & Issue Addressed & Objective & Citation \\
\hline Ganges River Basin & $\begin{array}{l}\text { Analysing the impact of market-based water transfer on } \\
\text { mitigating water scarcity and resolving transboundary water } \\
\text { conflict in the Basin. }\end{array}$ & $\begin{array}{l}\text { Prediction } \\
\text { Planning }\end{array}$ & [99] \\
\hline \multirow{3}{*}{ Nile River Basin } & $\begin{array}{l}\text { Proposing a new Nile water agreement based on allocate and } \\
\text { trade scheme }\end{array}$ & $\begin{array}{l}\text { Prediction } \\
\text { Planning }\end{array}$ & [100] \\
\hline & $\begin{array}{l}\text { Evaluating a market solution for water sharing in Eastern Nile } \\
\text { Basin based on allocate-and-trade approach by comparing its } \\
\text { possible economic benefits to that of a social planner solution }\end{array}$ & $\begin{array}{l}\text { Prediction } \\
\text { Planning }\end{array}$ & [96] \\
\hline & $\begin{array}{l}\text { Combing Market approach with cooperative game theoretic } \\
\text { framework to assess the stability of possible water allocation } \\
\text { agreements of the Eastern Nile Basin }\end{array}$ & $\begin{array}{l}\text { Prediction } \\
\text { Planning }\end{array}$ & [101] \\
\hline $\begin{array}{l}\text { The Euphrates } \\
\text { River }\end{array}$ & $\begin{array}{l}\text { Based on a model developed to maximize the economic benefits of } \\
\text { the Euphrates water system, the study proposes a water trading } \\
\text { mechanism between Syria and Turkey to overcome water scarcity. }\end{array}$ & $\begin{array}{l}\text { Prediction } \\
\text { Planning }\end{array}$ & [102] \\
\hline \multirow{3}{*}{ Middle East Region } & $\begin{array}{l}\text { Developing a model for a free water market between Palestine, } \\
\text { Jordan and Israel. }\end{array}$ & $\begin{array}{l}\text { Prediction } \\
\text { Planning }\end{array}$ & [103] \\
\hline & $\begin{array}{l}\text { Evaluating two possible mechanisms, percentage claims and } \\
\text { priority claims, for establishing regional water markets in the } \\
\text { eastern Middle East region (Palestine, Egypt, Jordan and Israel) by } \\
\text { comparing them to the social planner option }\end{array}$ & $\begin{array}{l}\text { Prediction } \\
\text { Planning }\end{array}$ & {$[97]$} \\
\hline & $\begin{array}{l}\text { analysing the option of establishing regional water markets in the } \\
\text { eastern Mediterranean region (Palestine, Egypt, Syria Jordan and } \\
\text { Israel, Turkey) by comparing them to the social planner option }\end{array}$ & $\begin{array}{l}\text { Prediction } \\
\text { Planning }\end{array}$ & [7] \\
\hline Lake Constance & $\begin{array}{l}\text { Comparing the management capacity of states and markets using } \\
\text { Lake Constance as an example of efficient transboundary market } \\
\text { institutions. }\end{array}$ & $\begin{array}{l}\text { Explanation } \\
\text { Analysis }\end{array}$ & [104] \\
\hline
\end{tabular}

Although Water market mechanism has been celebrated by various academics as an efficient solution for transboundary water conflicts, four realities have challenged it. Firstly, transboundary water basins need to have a large number of agents to yield an efficient equilibrium. One of the main conditions necessary to yield an efficient allocation of resources is having a large number of sellers and buyers. The number of riparian countries sharing any basin, even in the case of large river basin, cannot satisfactorily meets this condition. This market failure is compounded by the fact the most basins are characterised by a difference bargain power among sharing countries. Secondly, another necessary condition of efficient allocation of resources is the independence of actor's actions. Actions by agents should not affect other agents, except through the price mechanism. However, in the transboundary water basins, the actions of agents may affect each other as a result of the interdependence that characterise transboundary water basins. Thirdly, it is difficult to establish well-defined property rights when dealing with countries with cultural differences and traditional systems that have regulated these basins for long time, especially in the absence of a robust international law doctrine on transboundary water resources management. These market failures has limited the power of water market approach as a transboundary water conflict resolution mechanism, as it assumes an idealised process of water allocation, ignoring the conflict environment and its constraints (Figure 5). Finally, it does not take the 
connecting micro-processes of negotiations that add up to form the process of conflict resolution into consideration. These limitations have induced researchers to resort to another theoretical framework used to analyse imperfect-competitive market structures, which is game theory.

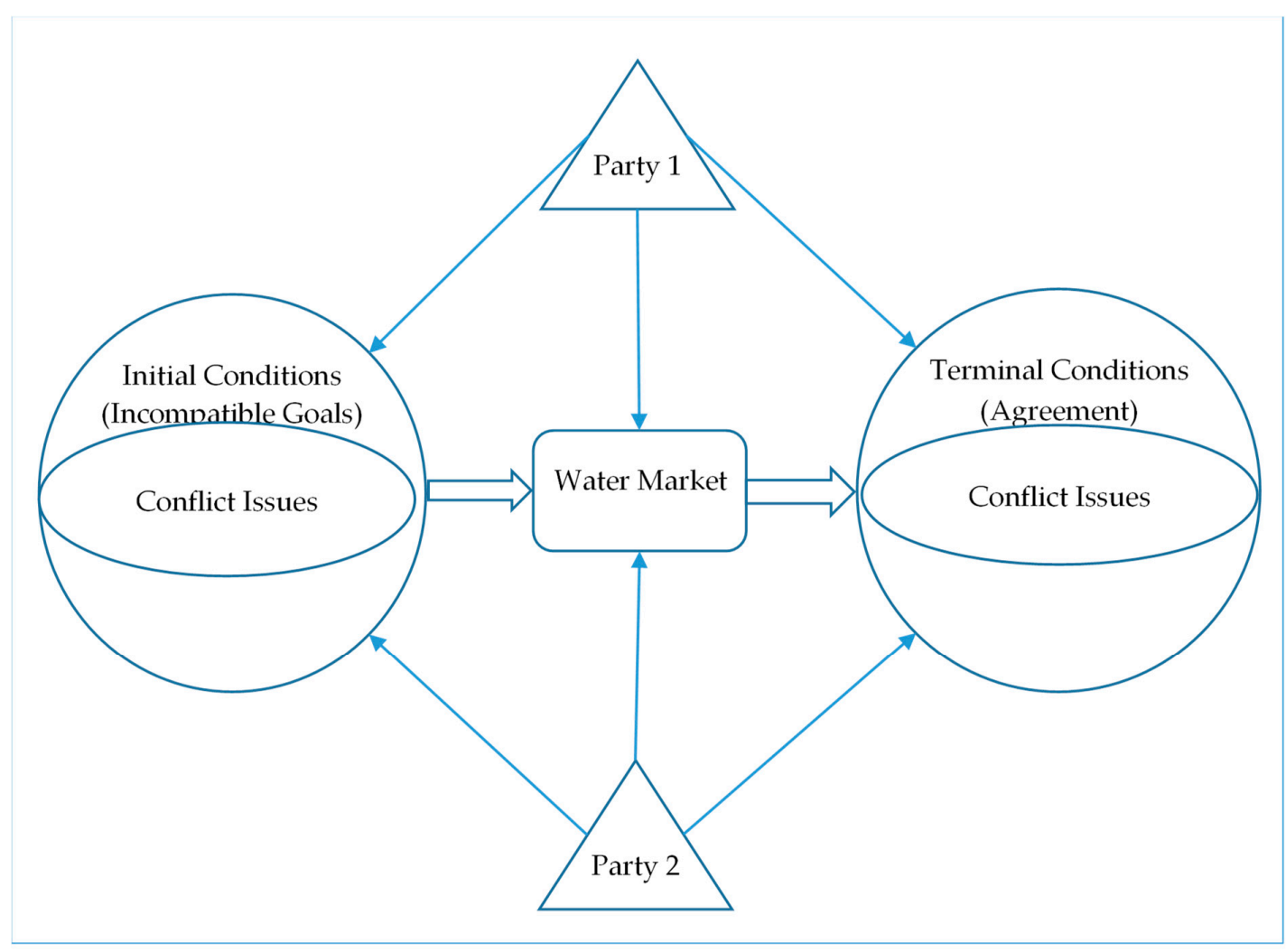

Figure 5. Structure of Water Market Mechanism.

\subsubsection{Game Theory}

Game theory is another economic mechanism that has been used to address transboundary water resources management and conflict resolution. Game theory adopted the main assumption of classical economic thinking and developed a new understanding of the utility and rationality concepts. This new perspective avoided the complex psychological explanation of the nature of rationality and utility [105]. The new understanding of rationality holds that an agent's choices are rational if they are internally consistent [106]. This internal consistency results from the fact that every human mind is constrained by certain general rules that are shaped by his personal experiences [107]. These rules form his expectations of possibility of future events and they influence his criteria of decision making. His utility function is the other factor that influences the decision making criteria. A new conception of utility, called subjective utility, has been developed by game theorists. Von Neumann and Morgenstern [108] were the first to develop this utility concept by integrating the risk factor into the conception of ordinal utility function, as introduced by Daniel Bernoulli in 1738, to map the decision preferences of each individual confronting risky options. This utility function, which is known as the subjective expected utility, is formed based on personal utility of agent and his personal probability distribution of possible outcomes. These two assumptions of consistent rationality and subjective utility, along with the assumption of scarcity of resources, form the basic behavioural conception of game theory.

Game theory differs from traditional economic analysis, in that it is multi-objective multi-agent interactive decision theory. It does not deal with decision situations in which actors are isolated, to avoid the impact from the influence of other actor's decisions and actions [109]. These interactions are claimed to be strategic, due to the fact that participants in such interactions are mutually aware of 
the mutual-effects of others' actions and actions are taken as a result of such cross-awareness [110]. Game theory has been used for three main types of analysis: explaining the development and outcome of real and experimental events, predicting the evolution and the outcome of already developing situations, and providing recommendations for influencing future interactions [110].

Games are classified into a few categories, according to the features of their context. For instance, they can be classified according to the sequence of play, the availability of information or the degree of conflict or coincidence of interests of players. One important classification that is worth emphasising is the categorisation of games into cooperative and non-cooperative games. This classification is used to distinguish between situations in which the actors establish an enforceable joint-action agreement and those in which they are not. The game is considered to be cooperative when the players can make such an enforceable joint agreement [110]. This cooperative game is a benefit-sharing situation, in which the players take not only their own payoff, but also the total payoff of all players into consideration [111]. Non-cooperative games materialise when the players act only in their own interests, even if cooperation among them emerges as a result of coincidence between their interests [110].

Game theory has provided a strong mechanism for addressing transboundary water resources conflicts. It has three main advantages over the conventional economic methods. First, it provides an analysis tool that maps the conflict resolution process, linking its dynamics to its potential output (Figure 4). Second, it has the capacity to analyse multi-criteria multi-decision maker interaction processes [8]. In the game models, each player optimises his objective, while remaining aware that others' decisions affect his payoff and that his decisions affect others' payoff. Last, the framework has strong tools and broad concepts that are capable of analysing not only individuals' action, but also state and organisational actors [112]. A unified actor does not necessarily perform actions, they might be the outcome of complex bureaucratic procedures or complicated tactics and changing the political coalitions [113]. Therefore, the application of game-theoretic frameworks as mechanisms for addressing the problem of transboundary water resources has generated considerable research interest in the past three decades (Table 5). Some researchers have resorted to cooperative game theory to tackle transboundary water basins, such as Columbia River Basin, Nile Basin, Euphrates and Tigris rivers, Jordan River Basin, and Ganges River Basin. Others have used the non-cooperative game theoretical mechanisms to analyse shared water resources, such as The Hirmand (Helmand) River, the Great Lakes between USA and Canada, and also the Nile Basin.

However, although a significant share of these studies aimed at predicting the future evolution of the water conflicts in these basins and suggested solutions to settle it, there is no evidence that any of them were put into action (Table 5). This can be attributed to some limitations of the studies that adopted game theory as their analytical framework. Firstly, these studies adopted the conventional game theory that has inherited the full-rationality assumption from the neoclassical economics. Laboratory experiments show that the analyses of games that are based on rational assumption sometimes fail to conform to the real events and situations [114]. "Polls and laboratory experiments indicate that people often fail to conform to some of the basic assumptions of rational decision theory" [115]. Self-interest maximisation is often quite difficult; in reality, most individuals and even specialists cannot conduct them [116]. Game theory ignores the constraints created by the conflict environment by assuming full rationality (Figure 6). Secondly, studies that used game theory have provided a macro-analysis of the process of conflict resolution but have not mapped the details of the connecting micro-processes of negotiations that could play a major role in defining the conflict settlement deal. Game theory has the power to analyse the micro-processes of negotiations (Figure 6). A recent study has used game theory to reflect the importance of linking the micro processes of negotiations to both the macro-process of water conflict resolution and conflict substance. However, most water conflict resolution studies have not linked the negotiations of micro-processes to the macro process of transboundary water conflict resolution. 
Table 5. Game-Theoretic Mechanism-Theory and Implementation.

\begin{tabular}{|c|c|c|c|}
\hline \multicolumn{4}{|c|}{ Game Theory } \\
\hline Problem Addressed & Issue Addressed & Objective & Citation \\
\hline \multirow[t]{2}{*}{ Columbia River Basin } & $\begin{array}{c}\text { Analysing the Columbia River scheme involving Canada and } \\
\text { USA using cooperative game theory. }\end{array}$ & $\begin{array}{l}\text { Explanation } \\
\text { Analysis }\end{array}$ & [117] \\
\hline & $\begin{array}{l}\text { Applying game theory, using the Graph Model for Conflict } \\
\text { Resolution to analyse the conflict between USA and Canada over } \\
\text { the Flathead River }\end{array}$ & $\begin{array}{l}\text { Prediction } \\
\text { Planning }\end{array}$ & [118] \\
\hline \multirow{4}{*}{ Nile River Basin } & $\begin{array}{l}\text { Applying game theory, using the Graph Model for Conflict } \\
\text { Resolution, to analyse the possible strategic behaviour of the Nile } \\
\text { riparian countries to determine the most likely outcomes. }\end{array}$ & $\begin{array}{l}\text { Prediction } \\
\text { Planning }\end{array}$ & {$[119,120]$} \\
\hline & $\begin{array}{c}\text { Applying cooperative game theory to the Nile Basin conflict to } \\
\text { evaluate the benefit of different options of cooperation }\end{array}$ & $\begin{array}{l}\text { Prediction } \\
\text { Planning }\end{array}$ & {$[121,122]$} \\
\hline & $\begin{array}{c}\text { Analysing the option of trading water technology } \\
\text { for interbrain water transfer among neighbouring } \\
\text { nations using cooperative game theory }\end{array}$ & $\begin{array}{l}\text { Prediction } \\
\text { Planning }\end{array}$ & {$[123,124]$} \\
\hline & $\begin{array}{l}\text { Combing Market approach with cooperative game theoretic } \\
\text { framework to assess the stability of possible water allocation } \\
\text { agreements of the Eastern Nile Basin }\end{array}$ & $\begin{array}{l}\text { Prediction } \\
\text { Planning }\end{array}$ & [101] \\
\hline $\begin{array}{l}\text { Euphrates and Tigris } \\
\text { rivers }\end{array}$ & $\begin{array}{l}\text { Combining linear programming and game theory to identify } \\
\text { stable water allocations that Syria, Iraq and Turkey accept. }\end{array}$ & $\begin{array}{l}\text { Prediction } \\
\text { Planning }\end{array}$ & {$[125,126]$} \\
\hline Jordan River & $\begin{array}{l}\text { Identifying possible option of sharing water through a } \\
\text { cooperative game theoretic with two players, Arabs and Israelis. }\end{array}$ & $\begin{array}{l}\text { Prediction } \\
\text { Planning }\end{array}$ & [127] \\
\hline \multirow{2}{*}{ Ganges River Basin } & $\begin{array}{c}\text { Combining linear programming and game theory to analyse the } \\
\text { alternatives for manage the river }\end{array}$ & $\begin{array}{l}\text { Prediction } \\
\text { Planning }\end{array}$ & [45] \\
\hline & $\begin{array}{l}\text { Combining optimisation and cooperative game theoretic methods } \\
\text { to identify feasible water sharing options in the Ganges Basin }\end{array}$ & $\begin{array}{l}\text { Prediction } \\
\text { Planning }\end{array}$ & [128] \\
\hline $\begin{array}{c}\text { Lower } \\
\text { Mekong River }\end{array}$ & $\begin{array}{l}\text { Applying cooperative game theory to analyse the Lower Mekong } \\
\text { river basin }\end{array}$ & $\begin{array}{l}\text { Prediction } \\
\text { Planning }\end{array}$ & [117] \\
\hline $\begin{array}{l}\text { Great Lakes between } \\
\text { USA and Canada }\end{array}$ & $\begin{array}{l}\text { Comparing social planner with non-cooperative game solutions to } \\
\text { the problem of water diversion from the lake highlight the } \\
\text { importance of cooperation between actors in the Great Lakes } \\
\text { Basin. }\end{array}$ & $\begin{array}{l}\text { Prediction } \\
\text { Planning }\end{array}$ & [93] \\
\hline \multirow[b]{2}{*}{ Rio Grande } & $\begin{array}{l}\text { Evaluating the cooperative options between the USA and Mexico } \\
\text { to reduce transboundary water pollution using non-cooperative } \\
\text { game theory }\end{array}$ & $\begin{array}{l}\text { Prediction } \\
\text { Planning }\end{array}$ & {$[129,130]$} \\
\hline & $\begin{array}{c}\text { Applying interconnected game approach to identify the linkages } \\
\text { between All-American Canal, Colorado River salinity and } \\
\text { wastewater projects of Rio-Grande } \\
\text { that are amenable to linked negotiations }\end{array}$ & $\begin{array}{l}\text { Prediction } \\
\text { Planning }\end{array}$ & [131] \\
\hline Colorado River & $\begin{array}{c}\text { Applying interconnected game approach to identify the linkages } \\
\text { between All-American Canal, Colorado River salinity and } \\
\text { wastewater projects of Rio-Grande } \\
\text { that are amenable to linked negotiations }\end{array}$ & $\begin{array}{l}\text { Prediction } \\
\text { Planning }\end{array}$ & [131] \\
\hline The Platte River & $\begin{array}{c}\text { Using cooperative game theoretic methods to determine share of } \\
\text { instream flow water each of the river-sharing states should } \\
\text { provide. }\end{array}$ & $\begin{array}{l}\text { Prediction } \\
\text { Planning }\end{array}$ & [132] \\
\hline Volta River Basin & $\begin{array}{l}\text { Using a stochastic Stackelberg differential game to identify } \\
\text { sustainable water-sharing arrangements that can be achieved by } \\
\text { linking transboundary water flows to hydropower exports. }\end{array}$ & $\begin{array}{l}\text { Prediction } \\
\text { Planning }\end{array}$ & [133] \\
\hline $\begin{array}{l}\text { The Hirmand } \\
\text { (Helmand) River }\end{array}$ & $\begin{array}{l}\text { Examining equilibria resulting from the application of different } \\
\text { stability definitions on the conflict modelled as non-cooperative } \\
\text { water resources game }\end{array}$ & $\begin{array}{l}\text { Prediction } \\
\text { Planning }\end{array}$ & [134] \\
\hline Caspian Sea & $\begin{array}{l}\text { Analysing the Caspian Sea conflict using a bankruptcy model, } \\
\text { based on cooperative game theory, to allocate oil and gas to the } \\
\text { littoral countries. }\end{array}$ & $\begin{array}{l}\text { Prediction } \\
\text { Planning }\end{array}$ & [135] \\
\hline
\end{tabular}




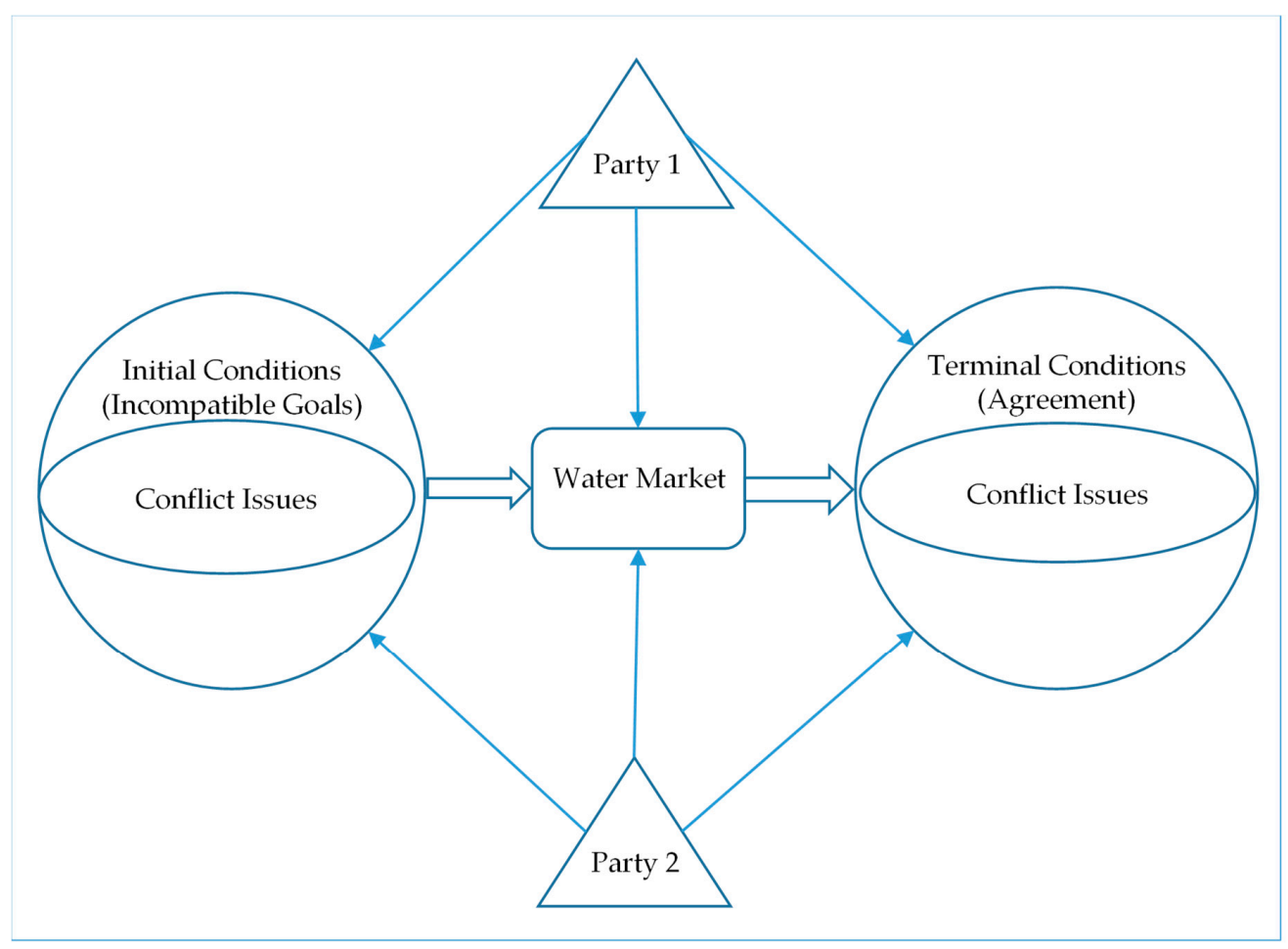

Figure 6. Structure of Game-Theoretic Mechanism.

\subsubsection{Institution-Constrained Game Approach: Institutional Analysis and Development}

A new framework has been developed to combine game theory and institutional analysis. Elinor Ostrom has constructed the Institutional Analysis and Development (IAD) framework as a model for strategic interaction among the users of common-pool resources. This framework can be considered as institution-constrained game analysis, or shortly institutional game analysis. This framework combines New Institutional Economics and non-cooperative game theory [136,137].

The New Institutional Economics (NIE) adopts an adapted version of neoclassical behaviour conception. It maintains its assumptions of utility-based motivation and competition over scarce resources [138]. However, it replaces the assumption of "full rational choice" with that of "bounded rationality" that was developed by Simon [116]. According to Simon, "human behaviour is intendedly rational but only boundedly so" [139]. Two constraints limit economic agents' rationality. The first is environment uncertainty, which results from environment complexities that are beyond the human mind capacity [140]. The second is the conflict of goals among agents resulting from the opportunistic behaviour of some of them [141].

North [142] developed his institutional environment model as a political economy framework, inspired by Simon's Assumptions. He defined institutions as constraints that human devise to reduce uncertainty through providing a structure to their daily lives [142]. Moreover, he defined the concept of the institutional environment as the meshwork composed of formal and informal institutions and their enforcement mechanisms that govern a society [143]. Formal institutions are the written laws, regulations, and agreements that govern politics and the economy [144]. Informal institutions are the unwritten social norms and taken-for-granted beliefs that constrain human behaviour [145]. Informal institutions, especially subconscious institutions, are persistent to change [146]. The institutional environment of a particular society defines property rights, provides the incentive structure that dictates the interactions of agents, and constrains their choices [143]. The importance of the role of institutions in making and constraining water resources governance system was highlighted by [147]. Ostrom has enlarged the concept of institutions to include not only rules (formal institutions) and norms (informal institutions), but also the strategies of the actors [148]. Subsequently, she developed 
an institution-constrained game theory analysis and applied it to water resources cooperation and conflict [148]. According to her, strategies are the regularised plans that are developed by actors within the incentive structure of the surrounding institutional environment and the expectations of the possible behaviour of others in a situation that is influenced by the relevant physical and material conditions [137].

IAD, as a mechanism of conflict resolution, is a variant of game theory with the explicit role of institutions (Figure 7). This explicit representation of institutions provided the power of mapping more accurately the water conflict resolution. Unfortunately, although the importance of institutions has become accepted as one of the main determinants of strategic interactions, such institutional game analysis has not yet attracted interest in the field of transboundary water conflict. Only two studies of the study of the Nile Basin [87] and the Jordan River [149] can be considered as the closest attempts to apply an analytical framework that is similar to Ostrom's institutional framework (Table 6). This could be explained in the light of three facts. The first is that this framework is relatively recent. The second is that the framework highlights the paramount role of the conflict environment by emphasising the role of institutions, especially informal institutions, in shaping the outcome of the conflicts over resources; it has not yet provided a method for accurately accounting for the impact of these institutions. Finally, most game theoretic approaches to transboundary conflict resolution have tended to focus on the actors' activities and the conflict environment, while also giving less attention to the conflict substance, which is water allocation. Although actors' activities and conflict environment are major determinants of the conflict resolution process, many transboundary basins suffer for a real problem of water scarcity, which can impede transboundary cooperation. Two other approaches have been developed which focus on the conflict substance, which is water scarcity as an impediment to transboundary water cooperation: benefit sharing and virtual water.

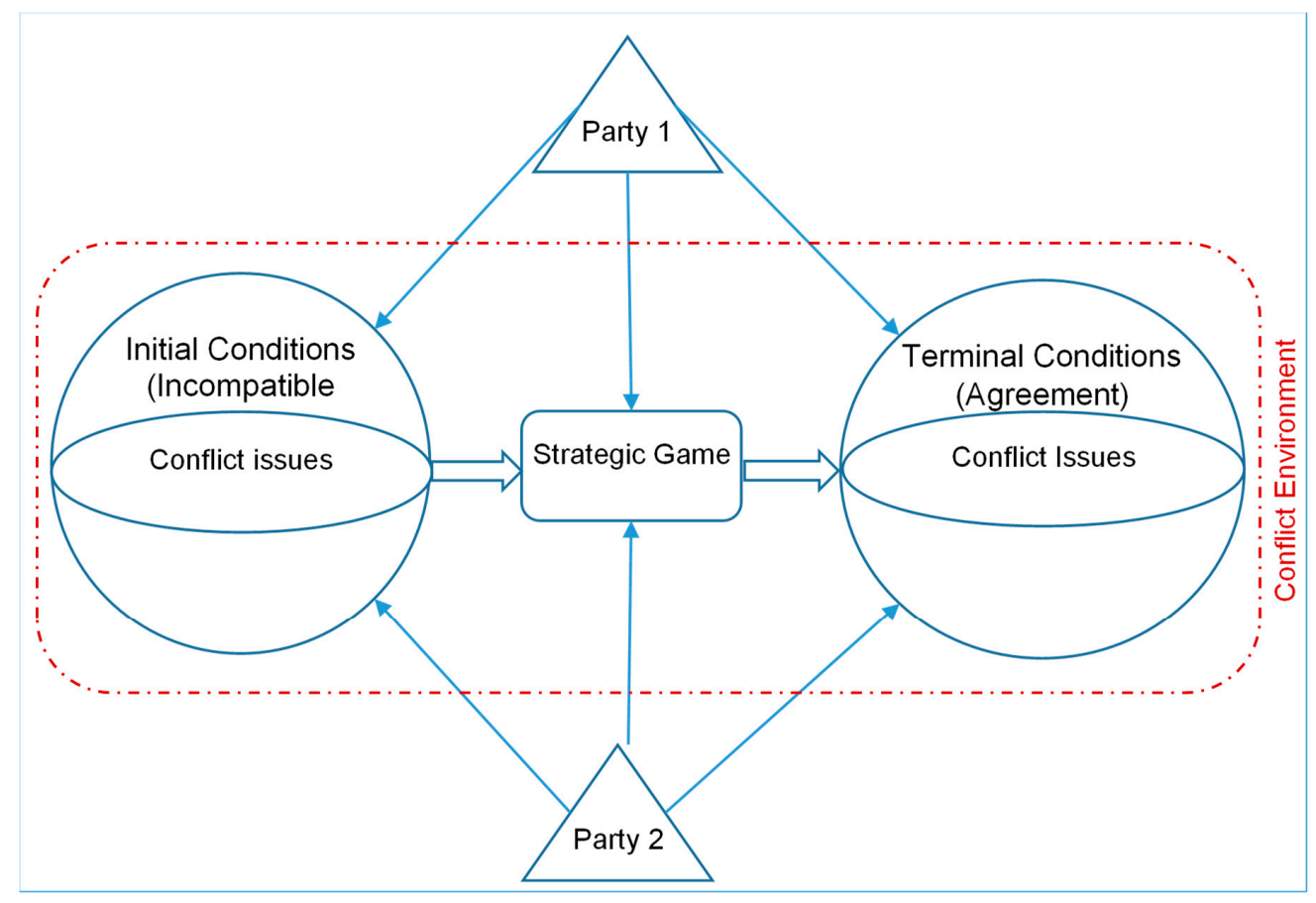

Figure 7. Structure of Institution-constrained Game Mechanism. 
Table 6. Institution-constrained Game Mechanism-Theory and Implementation.

\begin{tabular}{cccc}
\hline \multicolumn{1}{c}{ Institution-Constrained Game Theory Analysis } & & Issue Addressed \\
Addressed & \multicolumn{1}{c}{$\begin{array}{c}\text { Analysing the evolution of the Nile River governance system } \\
\text { Nile River Basin } \\
\text { using a framework combining non-cooperative game theory and } \\
\text { institutional analysis }\end{array}$} & $\begin{array}{c}\text { Explanation } \\
\text { Prediction }\end{array}$ & [87,150] \\
\hline Jordan River Basin & $\begin{array}{c}\text { analysing the negotiations process between Jordan and Israel over } \\
\text { the Jordan basin in the framework of collaborative negotiations } \\
\text { approach }\end{array}$ & $\begin{array}{c}\text { Explanation } \\
\text { Analysis }\end{array}$ & [149] \\
\hline
\end{tabular}

\subsubsection{Benefit-Sharing Perspective}

The basic idea of the benefit-sharing perspective is to widen the common property that is intended to be shared among water-sharing countries to enhance the potential for cooperation among them [151]. Thus, this perspective widens the shared property to water-related benefits instead of water. Water-related benefits can be classified into three major categories: environment-related; economic; and, security-related benefits [152]. The first category of cooperation benefits are the benefits that accrue to stakeholders from the improvement of the ecosystem of the river as a result of cooperation [153]. The second category of benefits derives from increased food and energy production that result from the efficient cooperative management of the river [153]. The third category of benefits derives from the reduction of defence costs because of minimising the tensions among riparian countries [153]. This perspective argues that widening the water-related benefits that are shared among water-sharing countries could facilitate transboundary water conflict resolution [154].

Benefit-sharing mechanism is still relatively recent and it has been limitedly used in explanation and analysis (Table 7). It introduces a view that can facilitate transboundary water conflict resolution. Nevertheless, benefit-sharing mechanism does not address the conflict resolution processes or the conflict environment, like the water market and social planner mechanisms (Figure 8). It assumes that a hypothetical benevolent conflict parties whose only concern and constraint is to maximise the overall economic welfare of their transboundary water basin.

Table 7. Benefit-sharing Mechanism—Theory and Implementation.

\begin{tabular}{cccc}
\hline $\begin{array}{c}\text { Problem } \\
\text { Addressed }\end{array}$ & Benefit-Sharing Perspective & Objective & Citation \\
\hline Nile River Basin & $\begin{array}{c}\text { Analysing the impact of Negotiations over the Grand Ethiopian } \\
\text { Renaissance Dam (GERD) on benefits sharing discourse in the } \\
\text { Eastern Nile Basin. }\end{array}$ & $\begin{array}{c}\text { Explanation } \\
\text { Analysis }\end{array}$ & [155] \\
\hline Jordan River Basin & $\begin{array}{c}\text { analysing the negotiations process between Jordan and Israel over } \\
\text { the Jordan basin in the framework of collaborative negotiations } \\
\text { approach }\end{array}$ & $\begin{array}{c}\text { Explanation } \\
\text { Analysis }\end{array}$ & [149] \\
\hline
\end{tabular}




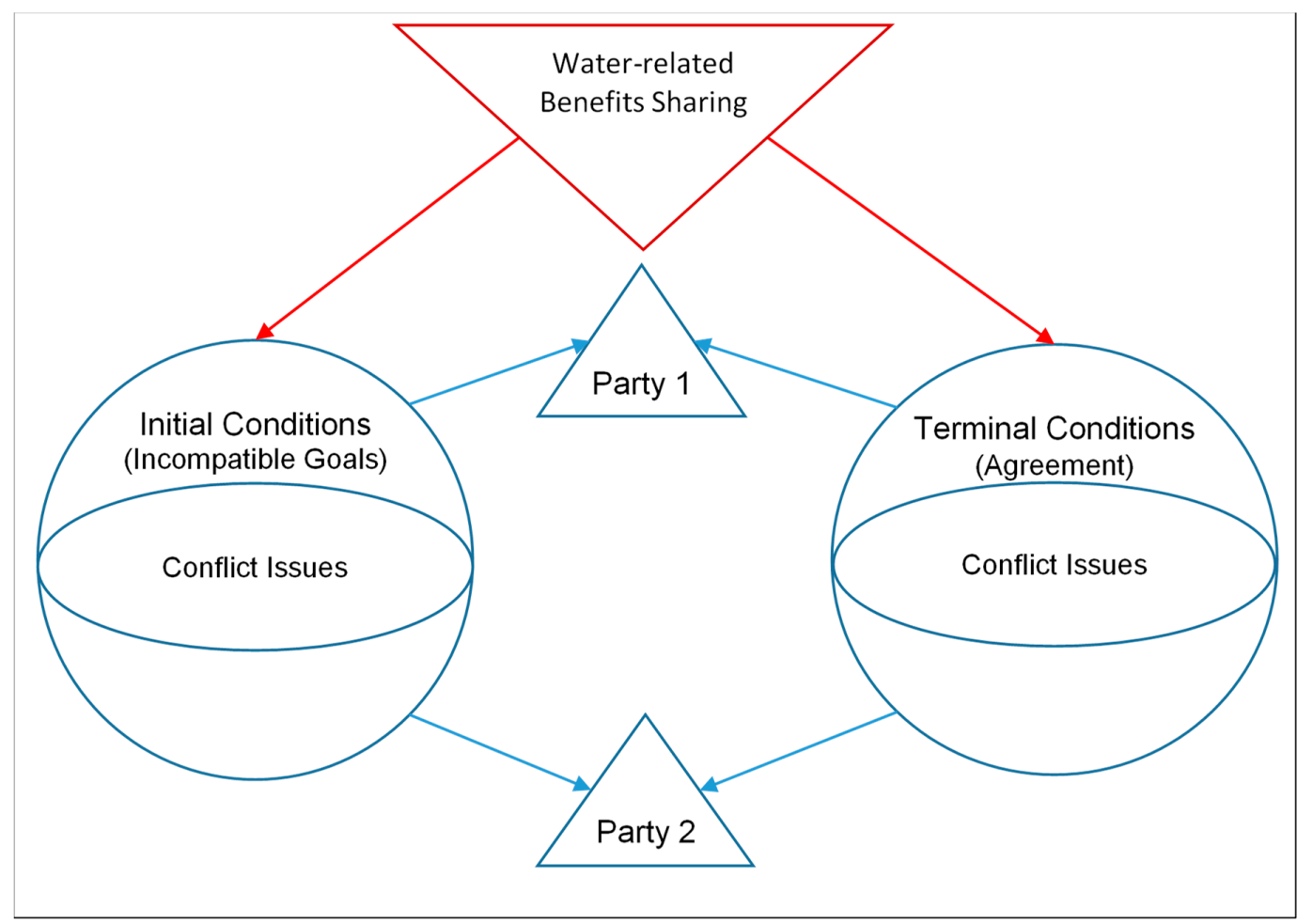

Figure 8. Structure of Benefit-Sharing Mechanism.

\subsubsection{Virtual Water}

The virtual water perspective has evolved over the past twenty-five years from being a positive perspective that explains the role that is played by food imports in addressing water deficits in water-scarce regions to a normative concept that could be implemented as a mechanism relieving water stress in transboundary water basins. The virtual water concept was developed and used by Allan $[40,156-163]$ to explain the role that is played food imports in addressing water deficits in water-scarce regions. Virtual water refers to the water embedded in a product that is traded in the global trading system [158]. The term virtual is used to highlight the fact that water embeddedness is not physical [164]. Virtual water describes the water that is consumed in the production of a product, not the water that is physically embodied in that product [164]. The term exogenous water is also used to describe virtual water to highlight the fact that it is exogenous source of water that a country adds to its indigenous water by importing food [165]. Furthermore, when a country in a transboundary water basin imports virtual water from outside this basin, it virtually adds exogenous water to the indigenous water of this basin [166]. Thus, virtual water import has been gradually developed to be mechanism that could help resolving transboundary water conflicts in the basins that suffer from water scarcity [11]. Allan [11] emphasises that the political economy context of water constrains the role of virtual water in a transboundary water basin, both on the national level and the basin-wide level. The impact of the social context of water is also identified as one of the major determinants of virtual water role in mitigating water deficit [167].

Although virtual water has been extensively applied as a national water policy mechanism to mitigate national water deficit, its application as a transboundary water conflict resolution mechanism has been quite recent (Table 8). The main strength of this mechanism is that it provides a revolutionary solution, an external virtual supply of water, which can effectively mitigate the transboundary water conflicts in basins that suffer from water scarcity. It also accounts for the economic, political, and social environments of transboundary conflicts (Figure 9). On the other hand, this perspective has deliberately abstained from addressing the conflict resolution process. This deliberate abstention is 
justified by the politicization and securitization of transboundary water conflicts that withdraw it from the public domain and limit intellectual access to its details [11].

Table 8. Virtual Water Mechanism-Theory and Implementation.

\begin{tabular}{cccc}
\hline & Virtual Water Perspective & & \\
\hline $\begin{array}{c}\text { Problem } \\
\text { Addressed }\end{array}$ & Issue Addressed & Objective & Citation \\
\hline Nile River Basin & Analysing the impact of virtual water imports on relieving the \\
water stress in Nile Basin. & $\begin{array}{c}\text { Explanation } \\
\text { Analysis }\end{array}$ & $\begin{array}{c}{[166,168,} \\
169]\end{array}$ \\
\hline Jordan River Basin & $\begin{array}{c}\text { Explaining the contribution of virtual water to relieve the water } \\
\text { scarcity and reduce the water-related tensions in the Jordan River } \\
\text { Basin }\end{array}$ & $\begin{array}{c}\text { Explanation } \\
\text { Analysis }\end{array}$ & {$[149,170]$} \\
\hline
\end{tabular}

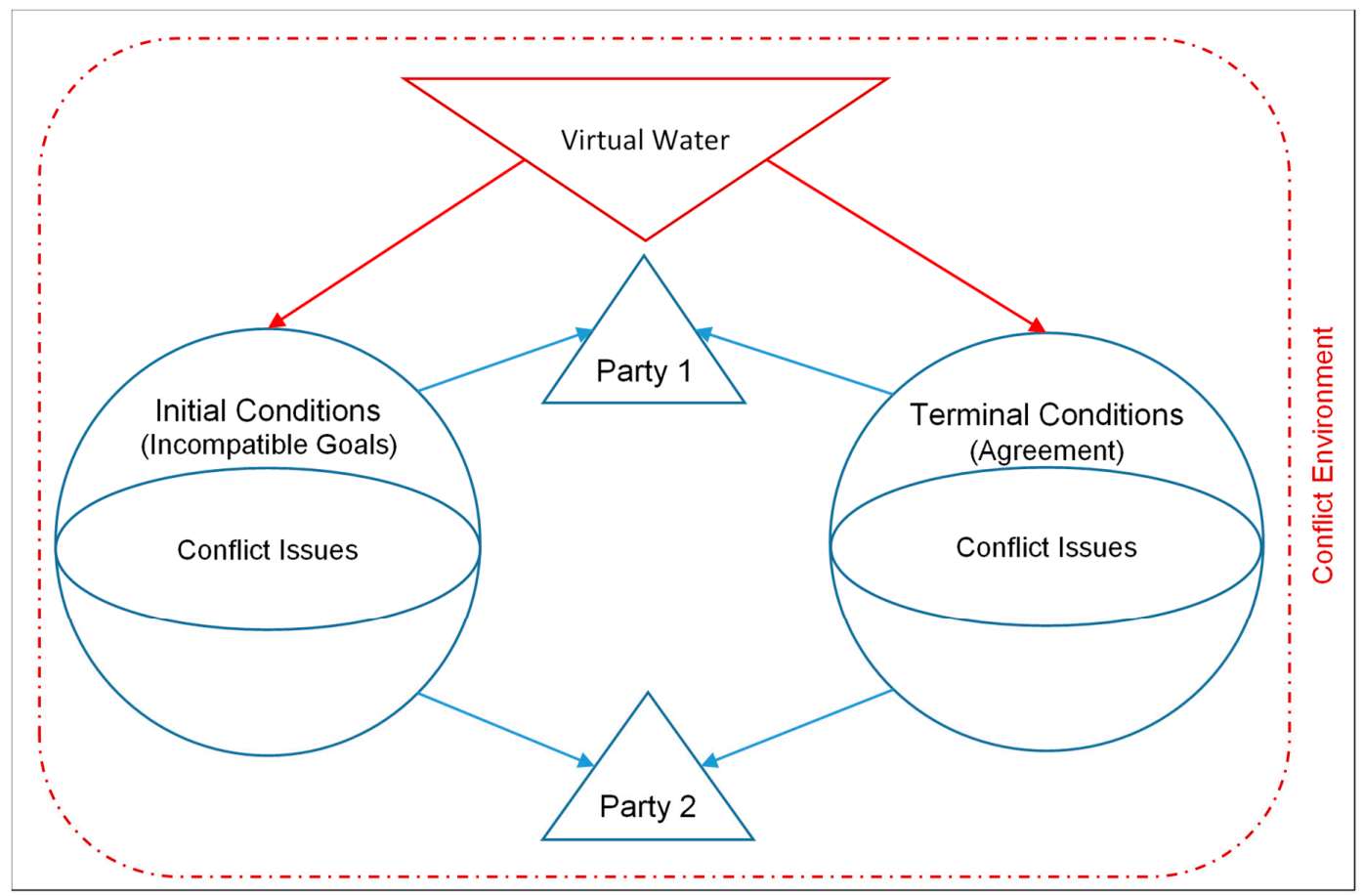

Figure 9. Structure of Virtual Water Mechanism.

\subsection{Political Perspective}

The political perspective to transboundary water conflicts is the latest addition to perspectives that addressed transboundary water conflict resolution. The political perspective to transboundary water conflicts highlights the significance of the influence of the political environment on transboundary water interactions $[159,171]$. For this perspective, it is political geography that determines transboundary water conflict and cooperation among water-sharing states, although physical geography determines the water supply characteristics in a transboundary basin and economic geography identifies the parameters of water demand in that basin [172]. Thus, political scholars criticise the other perspectives for depoliticising transboundary water conflicts and proposing either politically neutral engineering or economic solution [173]. Instead, they give politics centre stage on transboundary water interactions [174]. This perspective evolved over the past forty years [175] into two well-identified main intellectual lines: hydropolitics and critical hydropolitics.

\subsubsection{Hydropolitics}

Hydropolitics literature focuses on systematically studying the nature and dynamics of inter-state conflict and cooperation over transboundary water resources [176]. Hydropolitics can be considered 
as the mainstream political literature on transboundary water conflicts. The London Water Research Group (LWRG) mainly developed it in the past two decades [175]. LWRG was established by a group of scholars that was composed of students and colleagues of Professor John Anthony (Tony) Allan [177]. The group adopted his view of the dominance of role of politics on transboundary water issues $[11,177]$. They stress that politics authoritatively allocate values on society with respect to water, which constrains the transboundary water interactions [178]. This perspective has presented four main analytical frameworks that could be used as transboundary water conflict resolution mechanisms over the past two decades: Hydro-Hegemony, Transboundary Waters Interaction Nexus (TWINS), Dynamic Transboundary Water Interaction (DTWI), and Transformative Analysis.

The Hydro-hegemony framework has been presented as an explanatory mechanism that highlights the role of power asymmetry in determining the intensity of transboundary water interactions. Hydro-hegemony has argued that the more powerful party among water-sharing parties, or the hegemon maintains its control over the transboundary interactions by subordinating the parties through water resource control strategies that exploit the existing forms of hard and soft power in the transboundary water basin [179]. In this way, the hegemon maintains situations of non-violent water conflict [180]. Four power forms can exist in a transboundary water basin: geography; material power; bargaining power; and, ideational power [181]. Geographical position of a state in a transboundary water basin is the natural source of power that usually favours upstream states [9]. Material power comprises military power, economic power, technology, and international political support [181]. Bargaining power describes the capacity of a state to control the rules of the game and set agendas of transboundary water interaction [182]. Ideational power refers to the capacity of a state to impose and legitimise specific narratives or discourses in a transboundary water basin [181]. Dominant narratives or discourses can constrain and strengthen the transboundary water conflict resolution process [183]. They can also structure the flow of the transboundary water conflict resolution process [183]. According to this framework, the power asymmetry among the water-sharing states and their strategies in using it determine the allocation, planning, and management of transboundary water resources [184].

The Transboundary Waters Interaction NexuS (TWINS) framework has been introduced as an explanatory mechanism that can highlight the simultaneous coexistence of conflict and cooperation in transboundary water interactions [9]. On the one hand, the level of intensity of cooperation in each instance is determined by the existence or absence of four factors among the water-sharing states: common goals; joint action mechanism (s), will to participate in joint action mechanism, and confidence that other parties will to participate in collective action [162]. On the other, four levels of conflict can exist at each instance: non-politicized, politicized, securitized, and violised [11]. TWINS has offered a map that can analyse the patterns transboundary water interactions at any point of time based on these coexistent levels of cooperation and conflicts [185]. It can also trace the changes in the intensity of cooperation and conflict in transboundary water relations over time. An improvement has been introduced to TWINS by adding the degree of robustness of political economy the political economy context as third determinant of transboundary water interaction patterns [162].

The Dynamic Transboundary Water Interaction (DTWI) framework has been developed as an explanatory mechanism that can explain the dynamics of the changes in transboundary water inter-state relations. It combines the theoretical perspectives on counter-hegemony and change in order to analyse and explain the evolution of transboundary water inter-state relations [186]. It presents this evolution of transboundary relations as a struggle between contest and compliance [9]. The framework presents strategies that are used by water-sharing countries to establish and change transboundary water arrangements in transboundary water basins, including coercive, leverage, and liberating mechanisms [186]. According to this framework, a resistance that could be explicit or masked by "apparent" consent as counter-hegemonic tactic usually induces this process of change in the transboundary arrangements [9]. The outcome of Transboundary Water Interaction is determined by the net impact of simultaneous hegemonic and counter-hegemonic processes that shape new transboundary water arrangements [186]. 
The Transformative Analysis is the most recent analytical framework that is introduced by the hydropolitics scholars. It can be considered as the first hydropolitical mechanism that has been developed to be used for planning purposes [187]. The Transformative Analysis attempts to trace and analyse strategies that are used by water-sharing states to identify which of them can improve the inter-state power relations and establish sustainable transboundary water arrangements [187]. As this analytical framework has been very recently introduced, many of its ideas still need to be clarified and tested by applying it into real transboundary water conflicts.

\subsubsection{Critical Hydropolitics}

Critical hydropolitics is the second intellectual line of the political perspective to transboundary water interactions. It criticises the state-centred view of hydropolitics that examine transboundary water issues as state-centred issues [188]. It presents an analytical framework that focuses on socioecological networks that were developed around transboundary water resources, which can be local within one nation state or can transcend the water-sharing state borders [188]. The framework combines the elements of political and human-environment geography to highlight how the state-centred analysis could simplify the socioecological networks and misleads the efforts to resolve transboundary water conflicts [188]. Recent research by Cascão and Zeitoun [181] has attempted to combine a hydropolitical and critical hydropolitical frameworks in one merged framework in order to provide more accurate and detailed political analysis for transboundary water conflicts. Hussein carried out another form of integration between the hydropolitical and critical hydropolitical frameworks [189]. He analysed the dominant national water discourse, stressing the interdependence between the dominant national water discourses and the dominant inter-state hydropolitical discourse in the transboundary water basin [189].

The mechanisms that were introduced by the political perspective focus on overcoming the constraints that are imposed by the political environment on transboundary water interactions in order to enable facilitating transboundary water conflict resolution. As Figure 10 shows, they do not address the technical or the economic process that are needed to resolve transboundary water conflicts. The main objective of their theoretical framework is to analyse the political determinants of transboundary water interactions. These frameworks have been extensively applied over the past two decades as explanatory mechanisms of transboundary water conflicts (Table 9). Furthermore, the Transformative Analysis, as the latest addition to this perspective, attempts to change the political environment of transboundary water conflict in order to facilitate its resolution. Thus, when used in transboundary conflict resolution, these mechanisms can be considered as the preparatory mechanisms for these conflicts while using the mechanism that is offered by the engineering and economic perspective. However, it should be highlighted that the use of these political mechanisms in transboundary conflict resolution faces the extremely complex challenge that is emphasised by the godfather of the perspective, Professor Tony Allan, which is the difficulty of accessing the data and decision making circles in transboundary water conflicts [11]. 
Table 9. Political Mechanisms-Theory and Implementation.

\begin{tabular}{|c|c|c|c|}
\hline \multicolumn{4}{|c|}{ Political Perspective } \\
\hline $\begin{array}{l}\text { Problem } \\
\text { Addressed }\end{array}$ & Issue Addressed & Objective & Citation \\
\hline \multirow{5}{*}{ Nile River Basin } & $\begin{array}{l}\text { Using the hydro-hegemony framework to analyse the role of } \\
\text { hydro-political relations in shaping the water governance regime } \\
\text { in the Nile Basin. }\end{array}$ & $\begin{array}{l}\text { Explanation } \\
\text { Analysis }\end{array}$ & [180-182] \\
\hline & $\begin{array}{l}\text { Using an extended TWINS approach to analyse the role of } \\
\text { economic strength and diversification in shaping the trajectory of } \\
\text { Egypt-Sudan water interactions in the Nile Basin. }\end{array}$ & $\begin{array}{l}\text { Explanation } \\
\text { Analysis }\end{array}$ & {$[11,162]$} \\
\hline & $\begin{array}{l}\text { Using the conceptual framework of dynamic transboundary } \\
\text { water interaction to explain the changes in the Nile Basin. }\end{array}$ & $\begin{array}{l}\text { Explanation } \\
\text { Analysis }\end{array}$ & {$[186,190]$} \\
\hline & $\begin{array}{l}\text { Using the case of the Grand Ethiopian Renaissance Dam (GERD) } \\
\text { to scrutinise the hydro-hegemony framework hypothesis that } \\
\text { counter-hegemonic mechanisms produce a more equitable } \\
\text { transboundary water governance regime. }\end{array}$ & $\begin{array}{l}\text { Explanation } \\
\text { Analysis }\end{array}$ & {$[191,192]$} \\
\hline & $\begin{array}{l}\text { Using a hydro-hegemony framework to analyse the role of power } \\
\text { asymmetry in shaping patterns of hydropolitical relations in the } \\
\text { Nile Basin }\end{array}$ & $\begin{array}{l}\text { Explanation } \\
\text { Analysis }\end{array}$ & [174] \\
\hline \multirow{5}{*}{ Jordan River } & $\begin{array}{l}\text { Analysing the role of hydro-political relations in shaping the } \\
\text { water governance regime in the Jordan River Basin using the } \\
\text { hydro-hegemony framework. }\end{array}$ & $\begin{array}{l}\text { Explanation } \\
\text { Analysis }\end{array}$ & [180-182] \\
\hline & $\begin{array}{l}\text { Using an extended TWINS approach to analyse the role of } \\
\text { economic strength and diversification in shaping the trajectory of } \\
\text { Palestinian-Israeli water interactions over shared aquifers. }\end{array}$ & $\begin{array}{l}\text { Explanation } \\
\text { Analysis }\end{array}$ & {$[11,162]$} \\
\hline & $\begin{array}{l}\text { Using the conceptual framework of dynamic transboundary } \\
\text { water interaction to explain the stability in the Jordan river basin }\end{array}$ & $\begin{array}{l}\text { Explanation } \\
\text { Analysis }\end{array}$ & [186] \\
\hline & $\begin{array}{l}\text { Using a framework for discourse analysis to examine the role of } \\
\text { the dominant Israeli discourse in structuring the transboundary } \\
\text { water conflict resolution process in the Upper Jordan River Basin }\end{array}$ & $\begin{array}{l}\text { Explanation } \\
\text { Analysis }\end{array}$ & [183] \\
\hline & $\begin{array}{l}\text { Using a framework for discourse analysis to examine the } \\
\text { formation process of the dominance national water discourse in } \\
\text { Jordan, linking it to the transboundary water political and } \\
\text { hydropolitical relations. }\end{array}$ & $\begin{array}{l}\text { Explanation } \\
\text { Analysis }\end{array}$ & [189] \\
\hline \multirow{2}{*}{$\begin{array}{c}\text { Tigris and } \\
\text { Euphrates rivers }\end{array}$} & $\begin{array}{l}\text { Applying the hydro-hegemony framework to Identify the role of } \\
\text { hydro-political relations in shaping the water governance regime } \\
\text { in the Tigris and Euphrates Basin. }\end{array}$ & $\begin{array}{l}\text { Explanation } \\
\text { Analysis }\end{array}$ & [180-182] \\
\hline & $\begin{array}{l}\text { Using the conceptual framework of dynamic transboundary } \\
\text { water interaction to explain the changes in the Tigris river basin. }\end{array}$ & $\begin{array}{l}\text { Explanation } \\
\text { Analysis }\end{array}$ & [186] \\
\hline \multirow{3}{*}{ Mekong River } & $\begin{array}{l}\text { Using a critical hydropolitics framework to analyse how the } 1995 \\
\text { Agreement geopolitically framed the basin-wide water } \\
\text { interactions in interstate level, masking in this way water } \\
\text { interactions occurring at the level of communities and ecosystems. }\end{array}$ & $\begin{array}{l}\text { Explanation } \\
\text { Analysis }\end{array}$ & [188] \\
\hline & $\begin{array}{l}\text { Using a critical hydropolitics framework to how hydropower } \\
\text { dams connecting major power markets in China, Thailand and } \\
\text { Vietnam, are transforming the nature-society relations in countries } \\
\text { sharing the Lancang-Mekong River. }\end{array}$ & $\begin{array}{l}\text { Explanation } \\
\text { Analysis }\end{array}$ & [193] \\
\hline & $\begin{array}{l}\text { Using the conceptual framework of dynamic transboundary water } \\
\text { interaction to explain the changes in the Mekong River Basin. }\end{array}$ & $\begin{array}{l}\text { Explanation } \\
\text { Analysis }\end{array}$ & [186] \\
\hline Rio Grande & $\begin{array}{l}\text { Using a political-economy-constrained TWINS approach to } \\
\text { analyse the role of economic strength and diversification in } \\
\text { shaping the trajectory of water interactions in the Rio-Grande } \\
\text { Basin. }\end{array}$ & $\begin{array}{l}\text { Explanation } \\
\text { Analysis }\end{array}$ & [162] \\
\hline Amu Darya River & $\begin{array}{l}\text { Using the conceptual framework of dynamic transboundary water } \\
\text { interaction to explain the changes in the Amu Darya River Basin. }\end{array}$ & $\begin{array}{l}\text { Explanation } \\
\text { Analysis }\end{array}$ & [186] \\
\hline
\end{tabular}


Table 9. Cont.

\begin{tabular}{|c|c|c|c|}
\hline \multicolumn{4}{|c|}{ Political Perspective } \\
\hline $\begin{array}{l}\text { Problem } \\
\text { Addressed }\end{array}$ & Issue Addressed & Objective & Citation \\
\hline \multirow[t]{2}{*}{$\begin{array}{l}\text { Yarmouk River } \\
\text { Basin }\end{array}$} & $\begin{array}{l}\text { Using a discourse theory framework to maps relation between the } \\
\text { bilateral agreements on the Yarmouk River, the dominant } \\
\text { hydropolitical discourses. It also analyses the impact of these } \\
\text { dominant hydropolitical discourses and the proposed solution by } \\
\text { Jordan and Syria, taking into consideration the Power asymmetry } \\
\text { between the two countries. }\end{array}$ & $\begin{array}{l}\text { Explanation } \\
\text { Analysis }\end{array}$ & {$[184]$} \\
\hline & $\begin{array}{c}\text { Using a hydro-hegemony framework to analyse the role of power } \\
\text { asymmetry in shaping the evolving patterns of hydropolitical } \\
\text { relations in Yarmouk Basin }\end{array}$ & $\begin{array}{l}\text { Explanation } \\
\text { Analysis }\end{array}$ & {$[174]$} \\
\hline $\begin{array}{l}\text { The Guarani } \\
\text { Aquifer System }\end{array}$ & $\begin{array}{l}\text { Using a merged analytical framework that integrates critical } \\
\text { hydro-political framework into a hydro-hegemony framework to } \\
\text { analyse the role of power asymmetry between Argentina, Brazil, } \\
\text { Paraguay, and Uruguay in shaping the current formal water } \\
\text { governance's arrangements of The Guarani Aquifer System and } \\
\text { the informal cooperation arrangements between local } \\
\text { communities }\end{array}$ & $\begin{array}{l}\text { Explanation } \\
\text { Analysis }\end{array}$ & {$[194]$} \\
\hline \multirow{2}{*}{ Ganges River Basin } & $\begin{array}{l}\text { Applying an extended TWINS approach to explain the role of } \\
\text { economic strength and diversification in shaping the trajectory of } \\
\text { Nepal-India water interactions in the Ganges River Basin. }\end{array}$ & $\begin{array}{l}\text { Explanation } \\
\text { Analysis }\end{array}$ & {$[11,162]$} \\
\hline & $\begin{array}{l}\text { Using the conceptual framework of dynamic transboundary } \\
\text { water interaction to explain the stability in the Gangs river basin }\end{array}$ & $\begin{array}{l}\text { Explanation } \\
\text { Analysis }\end{array}$ & [186] \\
\hline Disi Aquifer & $\begin{array}{l}\text { Using a discourse theory framework to analyse the impact of the } \\
\text { water scarcity discourse in Jordan } \\
\text { on transboundary water governance of the Yarmouk River basin, } \\
\text { the Jordan River Basin and Disi Aquifer basin. }\end{array}$ & $\begin{array}{l}\text { Explanation } \\
\text { Analysis }\end{array}$ & [195] \\
\hline The Platte River & $\begin{array}{l}\text { Using a hydro-hegemony framework to highlight the impact of } \\
\text { hydropolitical regional hegemony on transboundary water } \\
\text { cooperation in in the La Plata River Basin and Guarani Aquifer } \\
\text { System. }\end{array}$ & $\begin{array}{l}\text { Explanation } \\
\text { Analysis }\end{array}$ & [196] \\
\hline
\end{tabular}

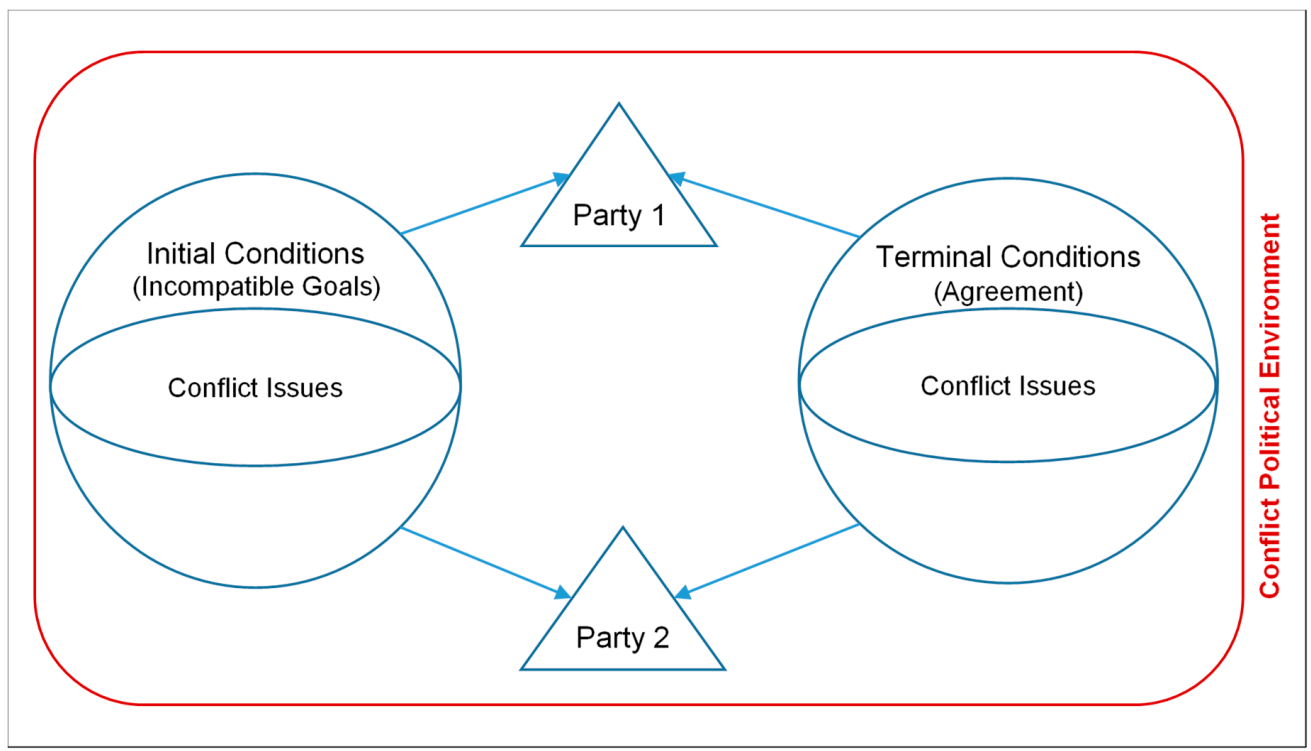

Figure 10. Structure of Political Mechanisms.

\subsection{Management Perspective}

The field of conflict management has focused on the process of negotiations with less attention being paid to the substance of conflict. Among the different perspectives of negotiations, the Alternative 
Dispute Resolution (ADR) approach can be considered as the line of thought that has provided new insights to negotiations [6]. Generally, ADR has generated considerable research attention among professional mediators and negotiator. However, recently, the contribution of academic researcher has been growing. The increasing importance of environmental conflicts has played an important role in the recent development of growing body of ADR literature.

The ADR literature focuses on re-centring negotiations around interests not positions [6]. ADR aims at reshaping the process of negotiations from distributive, or zero-sum, negotiations into collaborative negotiations. In collaborative negotiations, all of the parties cooperate to increase the overall outcome of the process, allowing for every party to gain from negotiations. Various frameworks of negotiations have been developed by the scholars of this field, but most of them rely on four main principles: defining the problem; focusing on interests and positions; getting parties together to generate new options; and, providing objective criteria for allocating the gains among parties.

As a process-based mechanism, ADR provides a detailed analysis of conflict resolution process. (Figure 11). It deals with the micro dynamics of the negotiations process in order to obtain the optimal results of it. However, it does not provide a concrete conceptualisation of the criteria that determine the optimal results. By providing the one-size-fits-all remedies, the ADR virtually excluded the conflict substance from the determinants of the evolution path of the process [197]. Therefore, the ADR could be considered as a partial conflict resolution mechanism that can serve as a process facilitation tool, but not as resolution mechanism that can guide the participants to optimal terminal conditions (Figure 11). Therefore, the ADR could be used as a complementary mechanism with other substance-based transboundary water conflict mechanisms.

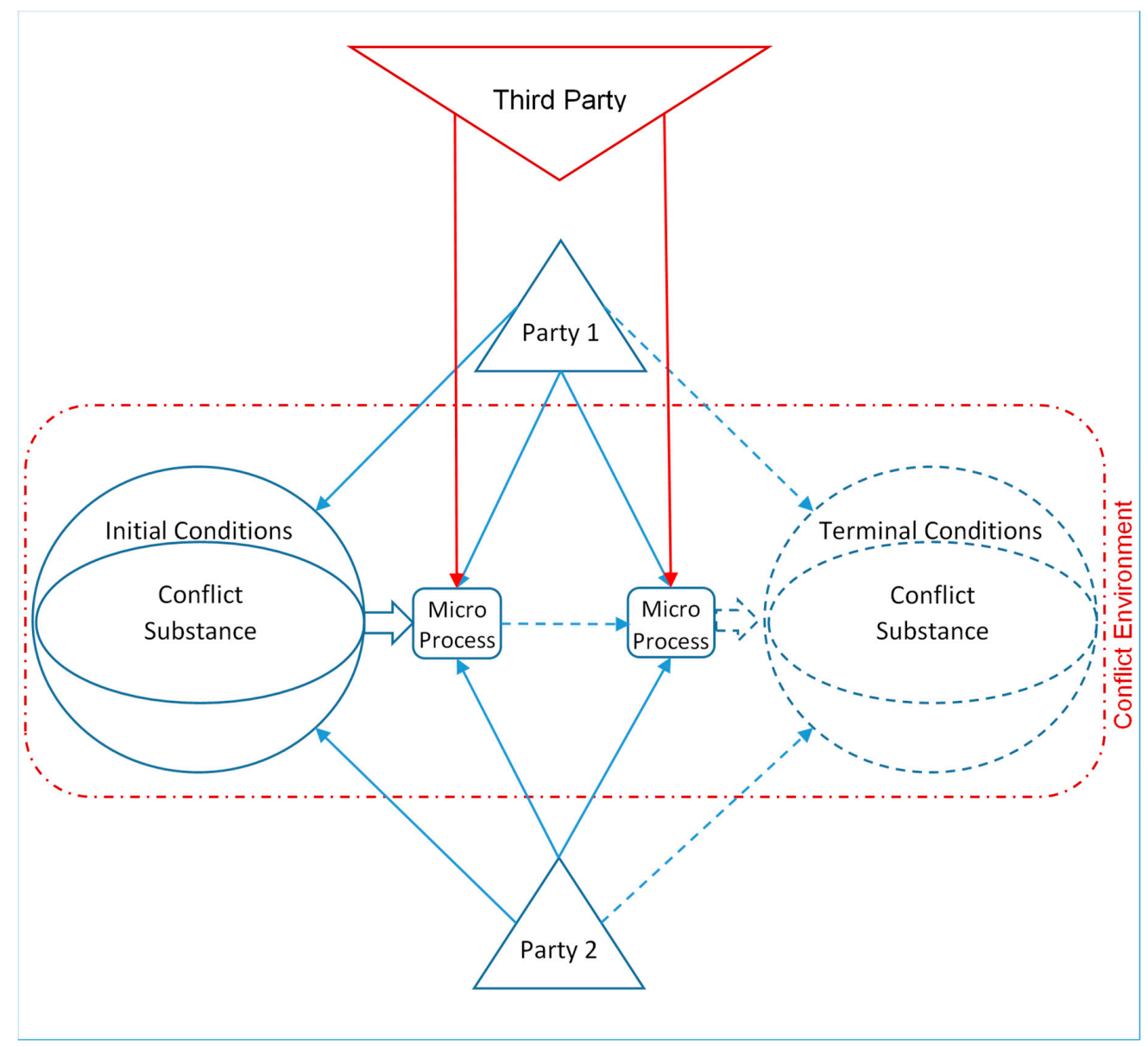

Figure 11. Structure of Alternative Dispute Resolution (ADR) Mechanism. 
Taking the complexity of transboundary water conflict resolution into consideration, ADR, as a process facilitator, has the potential to support the transboundary water resources negotiations. However, water conflicts generally have not attracted much research attention in this field. Few studies have addressed the conflicts in the Jordan River Basin, Caspian Sea, the Nile Basin, the Mekong River Basin, and the Ganges River Basin (Table 10). These studies focused on explaining the past or ongoing negotiations without giving concrete recommendation to facilitate solving these problems.

Table 10. Alternative Dispute Resolution Mechanism-Theory and Implementation.

\begin{tabular}{|c|c|c|c|}
\hline \multicolumn{4}{|c|}{ Alternative Dispute Resolution } \\
\hline $\begin{array}{l}\text { Problem } \\
\text { Addressed }\end{array}$ & Issue Addressed & Objective & Citation \\
\hline Caspian Sea & $\begin{array}{c}\text { Using descriptive approach identify the most likely outcomes of } \\
\text { the ongoing Caspian Sea negotiation according to the capabilities } \\
\text { of the decision makers and their preferences over the available } \\
\text { alternatives. }\end{array}$ & $\begin{array}{l}\text { Prediction } \\
\text { Planning }\end{array}$ & [198] \\
\hline The Mekong River Basin & $\begin{array}{l}\text { Investigating the negotiations for Mekong Agreement of } 1995 \\
\text { between Cambodia, Laos, Thailand, and Vietnam. }\end{array}$ & $\begin{array}{l}\text { Explanation } \\
\text { Analysis }\end{array}$ & [199] \\
\hline Nile River Basin & $\begin{array}{l}\text { Analysing the causes of failures and successes of the negotiations } \\
\text { process the Nile water using two explanatory approaches, the } \\
\text { Strategic Management Process (SMP) and Political Accounting } \\
\text { System (PAS). }\end{array}$ & $\begin{array}{l}\text { Explanation } \\
\text { Analysis }\end{array}$ & [200] \\
\hline \multirow{3}{*}{ Jordan River Basin } & $\begin{array}{l}\text { Evaluating the negotiations process between Jordan and Israel } \\
\text { over the Jordan basin management in the framework of } \\
\text { collaborative negotiations approach }\end{array}$ & $\begin{array}{l}\text { Explanation } \\
\text { Analysis }\end{array}$ & [149] \\
\hline & $\begin{array}{l}\text { Analysing the negotiations processes between Jordan and Israel of } \\
\text { 1950s and 1990s over the Jordan basin, comparing the impact of } \\
\text { the process on the resulted agreement in each case. }\end{array}$ & $\begin{array}{l}\text { Explanation } \\
\text { Analysis }\end{array}$ & [201] \\
\hline & $\begin{array}{l}\text { Examining the negotiation mechanisms and processes between } \\
\text { Syria, Turkey and Iraq in 1990s over Euphrates and Tigris rivers }\end{array}$ & $\begin{array}{l}\text { Explanation } \\
\text { Analysis }\end{array}$ & [202] \\
\hline Ganges River Basin & $\begin{array}{c}\text { Evaluating performance of the supporting institutional } \\
\text { mechanisms evolved over Time in the negotiations between India } \\
\text { and Bangladesh over waters-related issues in } \\
\text { Ganges-Brahmaputra-Meghna System. }\end{array}$ & $\begin{array}{l}\text { Explanation } \\
\text { Analysis }\end{array}$ & [203] \\
\hline
\end{tabular}

\section{Discussion and Conclusions}

This research aims at analysing the transboundary water conflicts resolution. Transboundary conflict resolution process is complex multi-dimensional process that needs a process-based approach to analyse it. This process-based analytical framework provided by us is called the mechanistic approach. A mechanism is analytical framework that provides extensive analysis of process and its elements; i.e., parties' goals, its initial conditions, terminal conditions, and environment constraints. The paper has attempted to map the major transboundary water conflict resolution mechanisms provided by the academic literature.

The literature that was reviewed revealed that the field of enquiry has influenced the focus of studies that have analysed transboundary water conflicts. Engineering studies have focused more on prediction and planning. Economics literature on transboundary water conflict resolution has had broad scope that covered both explanation and planning. Political analysis mainly concentrated on the explanation of the political constraints on transboundary water conflicts. Management studies have focused, in the very few studies that addressed transboundary water conflicts, on the explanation of water conflict resolution process.

Another major finding is the gap between theory and practice in the field of transboundary water conflict resolution. Although numerous studies have addressed the problems of transboundary water conflicts, very few of them have been used in reality for planning of water resources management. More specifically, the only theoretical transboundary water conflict resolution mechanism practiced was social planner, as Table 3 indicates. Two reasons behind this gap were identified by this review. 
The first was stressed by Allan [11], comprising the lack of academic access to the data and the decision making process in transboundary water conflicts, especially the critical and securitised conflicts.

The second is that almost transboundary water conflict resolution mechanisms that are offered by academic literature lack the analytical capacity to deal with all of the dimensions of transboundary water conflicts. This lack of analytical capacity stems from the uni-dimensionality of transboundary water conflict resolution mechanisms that are offered by academic literature. Almost all of these mechanisms have focused on dimendion of transboundary water conflicts, but not all of the dimensions. This uni-dimensionality was revealed by the analysis that was conducted in this study for the structure of the transboundary water conflict resolution mechanisms offered by the different academic fields. The study revealed that the structure of transboundary water conflict resolution mechanisms have also been determined by the field of enquiry (Figure 12). The majority of mechanisms developed in engineering and economics have focused on the conflict substance (Figure 12). These mechanisms include engineering-based mechanisms that relied on static models and economics-based mechanisms, such social planner and water markets. However, game theory and dynamic systems models have the analytical power to combine both the conflict substance as well as the conflict resolution process. Institution-constrained game theory, which is a recent variant of game theory, also has the capacity to include the external environment constraints. Although this capacity provides this recent game theory variant higher accuracy in analysing conflict resolution processes, it still needs to overcome the challenge of accurately modelling these constraints in its analysis. The political perspective focused on the conflict environment, namely the political environment, and its impact of the political constraints on these conflicts. Management studies is the last field of enquiry that addressed transboundary conflict resolution. These studies have focused on the micro-processes of the conflict resolution, i.e., the negotiations rounds. Although these parts of the conflict negotiation process have not been addressed by other mechanisms, it is not sufficient to reach a durable conflict resolution. Management studies needs to integrate the conflict substance in its structure to be capable of providing effective guidance to decision making.

Moreover, none of the mechanisms that were developed by the different disciplines have the analytical power to address all of the dimensions of transboundary conflict resolution (Table 11). Environment-focusing mechanisms that are offered by the political perspective have not addressed the macro- or the micro-processes of transboundary conflict resolution. However, these political mechanisms are essential in the preparatory stage for transboundary conflict resolution, but the solution needs to be generated by the engineering-based or economics-based mechanisms. Substance-focusing approaches, such as optimisation, social planner, and water markets, benefit-sharing, and virtual water do not have the capacity to map the macro and micro processes of conflict resolution. As indicated above, transboundary water conflict resolution is a complex process that needs a process-focusing analytical framework. Being devoid of a structure that can analyse this process deprives these from the defining feature of mechanism. To be a full mechanism, these approaches need to be complemented by other mechanism that are environment focusing-mechanisms that are offered by the political perspective and the process-based mechanisms. Similarly, pure process-based mechanisms, such as ADR and simulation models, need to integrate the conflict substance in its structure to be capable of providing effective guidance in decision making. Therefore, it also needs to be complemented by the above-referred environment focusing-mechanisms and substance-focusing mechanisms to acquire the analytical capacity that is needed to address all dimensions of transboundary water conflicts. 


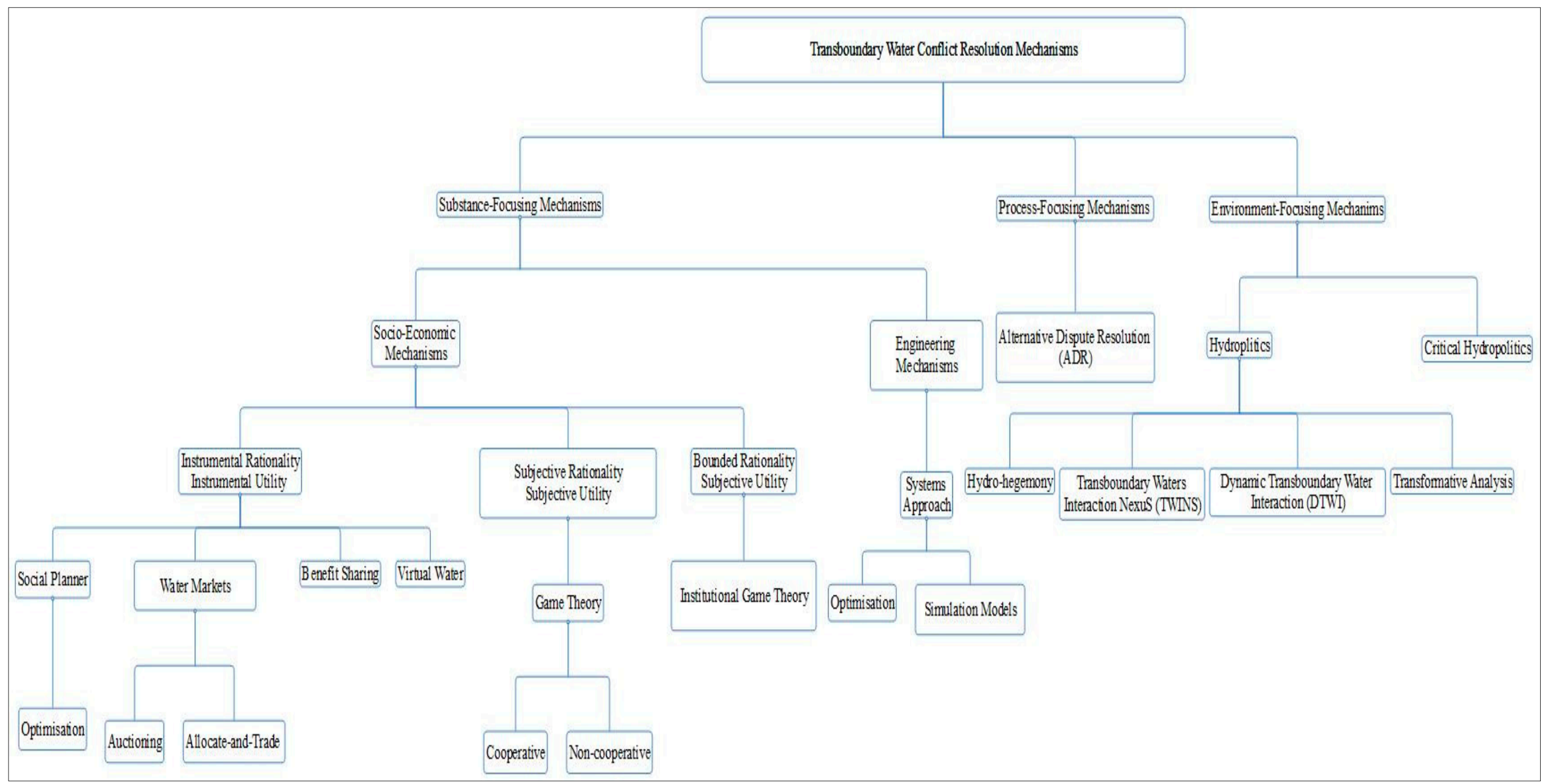

Figure 12. Transboundary Water Conflict Resolution Mechanisms—self-elaborated. 
Table 11. Transboundary water conflict resolution mechanisms: structural comparison—Self-elaborated.

\begin{tabular}{|c|c|c|c|c|c|c|c|c|}
\hline Field & Mechanism & $\begin{array}{c}\text { Initial } \\
\text { Conditions }\end{array}$ & $\begin{array}{c}\text { Macro-Process } \\
\text { Dynamics }\end{array}$ & $\begin{array}{l}\text { Micro-Processes } \\
\text { Dynamics }\end{array}$ & $\begin{array}{l}\text { Conflicts } \\
\text { Parties }\end{array}$ & $\begin{array}{l}\text { Third } \\
\text { Party }\end{array}$ & $\begin{array}{c}\text { Conflict } \\
\text { Environment } \\
\text { Constraints }\end{array}$ & $\begin{array}{c}\text { Terminal } \\
\text { Conditions }\end{array}$ \\
\hline \multirow{2}{*}{ Engineering } & Static Models & $\checkmark$ & $x$ & $x$ & $x$ & $\checkmark$ & $x$ & $\checkmark$ \\
\hline & Dynamic Models & $\checkmark$ & $\checkmark$ & $\checkmark$ & $x$ & $\checkmark$ & $\checkmark$ & $\checkmark$ \\
\hline \multirow{6}{*}{ Economics } & Social Planner & $\checkmark$ & $x$ & $x$ & $x$ & $\checkmark$ & $x$ & $\checkmark$ \\
\hline & Water Markets & $\checkmark$ & $x$ & $x$ & $\checkmark$ & $x$ & $x$ & $\checkmark$ \\
\hline & Game Theory & $\checkmark$ & $\checkmark$ & $x$ & $\checkmark$ & $x$ & $x$ & $\checkmark$ \\
\hline & Institution-Constrained Game Theory & $\checkmark$ & $\checkmark$ & $x$ & $\checkmark$ & $x$ & $\checkmark$ & $\checkmark$ \\
\hline & Benefit-sharing & $\checkmark$ & $x$ & $x$ & $\checkmark$ & $x$ & $x$ & $\checkmark$ \\
\hline & Virtual Water & $\checkmark$ & $x$ & $x$ & $\checkmark$ & $x$ & $\checkmark$ & $\checkmark$ \\
\hline \multirow{5}{*}{$\begin{array}{l}\text { Political } \\
\text { Perspective }\end{array}$} & Hydro-Hegemony & $\checkmark$ & $x$ & $x$ & $\checkmark$ & $x$ & $\checkmark$ & $\checkmark$ \\
\hline & Transboundary Waters Interaction Nexus (TWINS) & $\checkmark$ & $x$ & $x$ & $\checkmark$ & $x$ & $\checkmark$ & $\checkmark$ \\
\hline & Dynamic Transboundary Water Interaction (DTWI) & $\checkmark$ & $x$ & $x$ & $\checkmark$ & $x$ & $\checkmark$ & $\checkmark$ \\
\hline & Transformative Analysis. & $\checkmark$ & $x$ & $x$ & $\checkmark$ & $x$ & $\checkmark$ & $\checkmark$ \\
\hline & Critical Hydropolitics & $\checkmark$ & $x$ & $x$ & $\checkmark$ & $x$ & $\checkmark$ & $\checkmark$ \\
\hline Management & Alternative Dispute Resolution & $\checkmark$ & $x$ & $\checkmark$ & $\checkmark$ & $\checkmark$ & $\checkmark$ & $x$ \\
\hline
\end{tabular}


In sum, most of the theoretical mechanisms that were provided by literature have not possessed the analytical capacity to address all of the elements of transboundary water conflict resolution processes. Nevertheless, many of these mechanisms exhibit complementarity and they can be combined together to form a mechanism with strong analytical capacity. Therefore, it can be useful if academic research can examine the potential of using hybrid mechanisms that integrate two or more of the above-examined mechanisms to analyse the existing transboundary water conflict resolution. In this way, literature can provide practitioners with conflict resolution tools that can help them to resolve some of persistent transboundary water conflicts. However, it is important to stress that the use of these integrated mechanisms requires more collaboration and openness by practitioner to research and academic community.

Funding: This research received no external funding.

Acknowledgments: I would like to deeply thank John Anthony (Tony) Allan, Alexandra Collins, Kaveh Madani, Antonio Ramos, Fernando Alonso and Julian Walker for their guidance for this research work and express my sincere gratitude and appreciation for their comments, which greatly improved this manuscript. I would like also to thank the anonymous reviewers for their insightful comments on the first draft of this article.

Conflicts of Interest: The author declares no conflict of interest.

\section{References}

1. UN Water. Transboundary Waters: Sharing Benefits, Sharing Responsibilities; UN Water: Zaragoza, Spain, 2008.

2. Beach, H.L.; Hamner, J.; Hewitt, J.J.; Kaufman, E.; Kurki, A.; Oppenheimer, J.A.; Wolf, A.T. Transboundary Freshwater Dispute Resolution: Theory, Practice, and Annotated References; UNU Press: Tokyo, Japan, 2000.

3. Hornby, A.S.; Cowie, A.P. Oxford Advanced Learner's Dictionary; Oxford University Press: Oxford, UK, 1995; Volume 1430.

4. Delli Priscoli, J.; Wolf, A.T. Crafting institutions: Law, treaties, and shared benefits. In Managing and Transforming Water Conflicts; Delli Priscoli, J., Wolf, A.T., Eds.; Cambridge University Press: Cambridge, UK, 2009.

5. Lee, D.J.; Dinar, A. Review of Integrated Approaches to River Basin, Planning, Development and Management; The World Bank: Washington, DC, USA, 1995.

6. Delli Priscoli, J.; Wolf, A.T. Water conflict management: Theory and practice. In Managing and Transforming Water Conflicts; Delli Priscoli, J., Wolf, A.T., Eds.; Cambridge University Press: Cambridge, UK, 2009; pp. 33-49.

7. Becker, N. Reallocating Water Resources in the Middle East through Market Mechanisms. Int. J. Water Resour. Dev. 1996, 12, 17-32. [CrossRef]

8. Madani, K. Game theory and water resources. J. Hydrol. 2010, 381, 225-238. [CrossRef]

9. Eynon, K. Powerful Water: A Literature Review of Transboundary Water Interaction in the Nile Basin; University of Cape Town: Cape Town, South Africa, 2016.

10. Delli Priscoli, J.; Wolf, A.T. Introduction. In Managing and Transforming Water Conflicts; Delli Priscoli, J., Wolf, A.T., Eds.; Cambridge University Press: Cambridge, UK, 2009; pp. xxi-xxiv.

11. Allan, J.A.T.; Mirumachi, N. Why negotiate? Asymmetric endowments, asymmetric power and the invisible nexus of water, trade and power that brings apparent water security. In Transboundary Water Management; Routledge: Abingdon, UK, 2013; pp. 26-39.

12. Bercovitch, J.; Kremenyuk, V.; Zartman, I.W. The SAGE Handbook of Conflict Resolution; Sage: Newcastle upon Tyne, UK, 2008.

13. Morwood, J. The Oxford Latin Minidictionary; Oxford University Press: Oxford, UK, 1995.

14. Coser, L.A. The Functions of Social Conflict; Routledge: Abingdon, UK, 1956; Volume 9.

15. Mack, R.W.; Snyder, R.C. The analysis of social conflict-Toward an overview and synthesis. Confl. Resolut. 1957, 1, 212-248. [CrossRef]

16. Deutsch, M. Conflict resolution: Theory and practice. Political Psychol. 1983, 4, 431-453. [CrossRef]

17. Ramsbotham, O.; Miall, H.; Woodhouse, T. Contemporary Conflict Resolution; Polity: Cambridge, UK, 2016.

18. Boulding, K.E. Conflict and Defence A General Theory; Harper \& Row, Publishers: New York, NY, USA, 1962.

19. Galtung, J. Theories of conflict: Definitions, Dimensions, Negations, Formations; Transcend: Oslo, Norway, 2009. 
20. Deutsch, M.; Coleman, P.T.; Marcus, E.C. The Handbook of Conflict Resolution: Theory and Practice, 2nd ed.; John Wiley \& Sons: San Francisco, CA, USA, 2006.

21. Tilly, C. Mechanisms in political processes. Annu. Rev. Political sci. 2001, 4, 21-41. [CrossRef]

22. Hempel, C.G. The function of general laws in history. J. Philos. 1942, 39, 35-48. [CrossRef]

23. Elster, J. Nuts and Bolts for the Social Sciences; Cambridge University Press: Cambridge, UK, 1989.

24. Clayton, R. The Logic of Historical Explanation; Pennsylvania State University Press: University Park, PA, USA, 1996.

25. Abbott, A. Mechanisms and relations. Sociologica 2007, 1, 1-22.

26. Hedström, P.; Swedberg, R. Social Mechanisms: An Analytical Approach to Social Theory; Cambridge University Press: Cambridge, UK, 1998.

27. Hernes, G. 4. Real virtuality. In Social Mechanisms: An Analytical Approach to Social Theory; Hedström, P., Swedberg, R., Eds.; Cambridge University Press: Cambridge, UK, 1998; p. 74.

28. Machamer, P.; Darden, L.; Craver, C.F. Thinking about mechanisms. Philos. Sci. 2000, 67, 1-25.

29. Glennan, S. Rethinking mechanistic explanation. Philos. Sci. 2002, 69, S342-S353. [CrossRef]

30. Woodward, J. What is a mechanism? A counterfactual account. Philos. Sci. 2002, 69, S366-S377.

31. Bechtel, W.; Abrahamsen, A. Explanation: A mechanist alternative. Stud. Hist. Philos. Sci. Part C Stud. Hist. Philos. Biol. Biomed. Sci. 2005, 36, 421-441. [CrossRef]

32. Gross, N. A pragmatist theory of social mechanisms. Am. Sociol. Rev. 2009, 74, 358-379. [CrossRef]

33. Little, D. New Contributions to the Philosophy of History; Springer Science \& Business Media: Berlin/Heidelberg, Germany, 2010; Volume 6.

34. Illari, P.M.; Williamson, J. What is a mechanism? Thinking about mechanisms across the sciences. Eur. J. Philos. Sci. 2012, 2, 119-135.

35. Elster, J. A plea for mechanisms. In Social Mechanisms: An Analytical Approach to Social Theory; Hedström, P., Swedberg, R., Eds.; Cambridge University Press: Cambridge, UK, 1998; pp. 45-73.

36. Coleman, J.S. Social theory, social research, and a theory of action. Am. J. Sociol. 1986, 91, 1309-1335. [CrossRef]

37. Himes, J.S. Conflict and Conflict Management; University of Georgia Press: Athens, GA, USA, 1980.

38. Mitchell, C.R. The Structure of International Conflict; Macmillan Press: London, UK, 1981.

39. Simonovic, S.P. Managing Water Resources: Methods and Tools for a Systems Approach; Routledge: Abingdon, UK, 2012.

40. Nandalal, K.D.W.; Simonovic, S.P. State-of-the-Art Report on Systems Analysis Methods for Resolution of Conflicts in Water Resources Management; UNESCO: Paris, France, 2002.

41. Read, L.; Madani, K.; Inanloo, B. Optimality versus stability in water resource allocation. J. Environ. Manag. 2014, 133, 343-354. [CrossRef] [PubMed]

42. Nachtnebel, H. Views on international water conflicts: The referee's position and bilateral agreements. In Negotiation Over Water. Proceedings of the Haifa Workshop. IHP-V Technical Documents in Hydrology; Shamir, U., Ed.; UNESCO: Paris, France, 2001.

43. Sreenath, S.; Vali, A.; Susiarjo, G. The Nile River Problematique: An integrated look at the future of Egypt and Ethiopia. Water Int. 2002, 27, 517-531. [CrossRef]

44. Geressu, R.T.; Harou, J.J. Screening reservoir systems by considering the efficient trade-offs-Informing infrastructure investment decisions on the Blue Nile. Environ. Res. Lett. 2015, 10, 125008. [CrossRef]

45. Rogers, P. A game theory approach to the problems of international river basins. Water Resour. Res. 1969, 5, 749-760. [CrossRef]

46. Vali, A.; Sreenath, S.; Susiarjo, G. A systems approach to validating the water vision of the Aral Sea Basin. Water Int. 2006, 31, 157-168. [CrossRef]

47. Dukhovny, V.A.; Sokolov, V. Lessons on Cooperation Building to Manage Water Conflicts in the Aral Sea Basin; UNESCO: Paris, France, 2003.

48. Ganoulis, J. Water resources management and environmental security in Mediterranean transboundary river basins. In Environmental Security and Environmental Management: The Role of Risk Assessment; Springer: Berlin/Heidelberg, Germany, 2006; pp. 49-58.

49. Madani, K.; Sheikhmohammady, M.; MokhtariB, S.; Moradi, M.; Xanthopoulos, P. Social Planner's Solution for the Caspian Sea Conflict. Group Decis. Negot. 2013, 23, 579-596. [CrossRef] 
50. Siegfried, T.; Kinzelbach, W. A multiobjective discrete stochastic optimization approach to shared aquifer management: Methodology and application. Water Resour. Res. 2006, 42. [CrossRef]

51. Rajasekaram, V.; Simonovic, S.; Nandalal, K. Computer support for implementation of a systemic approach to water conflict resolution. Water Int. 2003, 28, 454-466. [CrossRef]

52. Nandalal, K.D.W.; Simonovic, S.P. Resolving conflicts in water sharing: A systemic approach. Water Resour. Res. 2003, 39. [CrossRef]

53. Yang, C.-C.; Chang, L.-C.; Ho, C.-C. Application of system dynamics with impact analysis to solve the problem of water shortages in Taiwan. Water Resour. Manag. 2008, 22, 1561-1577. [CrossRef]

54. Sánchez-Román, R.M.; Folegatti, M.V.; González, A.M.G.O. Water resources assessment at Piracicaba, Capivari and Jundiaí River Basins: A dynamic systems approach. Water Resour. Manag. 2010, 24, 761-773. [CrossRef]

55. Madani, K.; Mariño, M.A. System dynamics analysis for managing Iran's Zayandeh-Rud river basin. Water Resour. Manag. 2009, 23, 2163-2187. [CrossRef]

56. Madani, K. Water Transfer and Watershed Development: A System Dynamics Approach. In World Environmental and Water Resources Congress 2007: Restoring Our Natural Habitat; ASCE: Reston, VA, USA, 2007.

57. Sehlke, G.; Jacobson, J. System dynamics modeling of transboundary systems: The Bear River basin model. Ground Water 2005, 43, 722-730. [CrossRef] [PubMed]

58. Keith, B.; Enos, J.; Garlick, C.B.; Simmons, G.; Copeland, D.; Cortizo, M. Limits to Population Growth and Water Resource Adequacy in the Nile River Basin, 1994-2100. In Proceedings of the 31st International Conference of the System Dynamics Society, Cambridge, MA, USA, 21-25 July 2013.

59. Keith, B.; Horton, R.; Bower, E.; Lee, J.; Pinelli, A.; Dittrick, D. Water as a Conflict Driver: Estimating the Effects of Climate Change and Hydroelectric Dam Diversion on Nile River Stream Flow during the 21st Century; Center for Nation Reconstruction and Capacity Development: New York, NY, USA, 2014.

60. Bazrkar, M.H.; Nabavi, E.; Zamani, N.; Eslamian, S. System dynamic approach to hydro-politics in Hirmand transboundary river basin from sustainability perspective. Int. J. Hydrol. Sci. Technol. 2013, 3, 378-398. [CrossRef]

61. Hackett, C.S. Environmental and Natural Resources Economics: Theory, Policy, and the Sustainable Society; M.E. Sharpe, Inc.: New York, NY, USA, 2006.

62. Malthus, T. An Essay on the Principle of Population An Essay on the Principle of Population, as it Affects the Future Improvement of Society with Remarks on the Speculations of Mr. Godwin, M. Condorcet, and Other Writers; J. Johnson, St. Paul's Church-Yard: London, UK, 1798.

63. Jevons, W.S. The Coal Question: An Inquiry Concerning the Progress of the Nation, and the Probable Exhaustion of the Coal-Mines; Macmillan: London, UK, 1865.

64. Tietenberg, T.; Lewis, L. Environmental \& Natural Resource Economics; Pearson Education, Inc.: Hoboken, NJ, USA, 2012.

65. Bentham, J. An Introduction to the Principles of Morals and Legislation; Batoche Books: Kitchener, ON, Canada, 1781.

66. Mill, J.S. Utilitarianism; Dover Publications, Inc.: Dover, DE, USA, 1871.

67. Jevons, W.S. The Theory of Political Economy; Macmillan and Co.: London, UK, 1888.

68. Smith, A. An inquiry into the Nature and Causes of the Wealth of Nations; Liberty Press: Indianapolis, IN, USA, 1776.

69. Edgeworth, F.Y. Mathematical Physics: An Essay on the Application of Mathematics on Moral Sciences; C. Kegan Paul Co.: London, UK, 1881.

70. Simon, H.A. Rationality in Psychology and Economics. J. Bus. 1986, 59, S209-S224. [CrossRef]

71. Hussen, A.M. Principles of Environmental Economics; Routledge: London, UK, 2000.

72. Mankiw, G.N. Principles of Economics; South-Western College Publishing: Cincinnati, OH, USA, 2011.

73. Burkett, J.P. Microeconomics:Optimization, Experiments and Behavior; Oxford University Press: Oxford, UK, 2006.

74. Pigou, A.C. The Economics of Welfare; Macmillan and Co. Ltd.: London, UK; New York, NY, USA, 1920.

75. Gordon, H.S. The Economic Theory of a Common-Property Resource: The Fishery. J. Political Econ. 1954, 62, 124-142. [CrossRef]

76. Buchanan, J.M.; Stubblebine, W.C. Externality. Econ. New Ser. 1962, 29, 371-384. [CrossRef]

77. Randall, A. The Problem of Market Failure. Nat. Resour. J. 1983, 23, 131-148. 
78. Sheikhmohammady, M.; Madani, K. Bargaining over the Caspian Sea-The largest lake on the earth. In World Environmental and Water Resources Congress 2008: Ahupua'A.; ASCE: Reston, VA, USA, 2008.

79. Krutilla, J.V. The Columbia River Treaty: An International Evaluation; Resources for the Future: Washington, DC, USA, 1966.

80. Canada. Dept. of External Affairs, Canada. Dept. of Northern Affairs, and National Resources. The Columbia River Treaty: Protocol and Related Documents; R. Duhamel, Queen's Printer: Ottawa, ON, Canada, 1964.

81. Willcocks, W. Report on Perennial Irrigation and Flood Protection of Egypt; National Printing House: Cairo, Egypt, 1894.

82. Garstin, W. Dispatch from His Majesty's Agent and Consul-General at Cairo Inclosing a Report as to Irrigation Projects on the Upper Nile; His Majesty's Stationary Office: London, UK, 1901.

83. Garstin, W.; Dupuis, C. Dispatch from His Majesty's Agent and Consul-General at Cairo Inclosing a Report upon the Basin of the Upper Nile with Proposals for the Improvement of the River; His Majesty's Stationary Office: London, UK; National Printing Department: Cairo, Egypt, 1904.

84. MacDonald, M. Nile Control; Government Press: Cairo, Egypt, 1920.

85. Foreign Office. Exchange of Notes between his Majesty's Government in the United Kingdom and the Egyptian Government in Regard to the Use of the Waters of the River Nile for Irrigation Purposes; His Majestys Stationary Office: London, UK, 1929.

86. Hurst, H.E.; Black, R.P.; Simaika, Y.M. The Nile Basin- Volume VII: The Future Conservation of the Nile; Ministry of Public Works: Cairo, Egypt, 1946.

87. Waterbury, J. The Nile Basin: National Determinants of Collective Action; Yale University Press: New Haven, CT, USA, 2002.

88. Tvedt, T. The River Nile in the Age of the British: Political Ecology E the Quest for Economic Power; The American University in Cairo Press: Cairo, Egypt, 2004.

89. Haynes, K.E.; Whittington, D. International Management of the Nile. Stage Three? Geogr. Rev. 1981, 71, 17-32. [CrossRef]

90. Whittington, D.; Wu, X.; Sadoff, C. Water resources management in the Nile basin: The economic value of cooperation. Water Policy 2005, 7, 227-252.

91. Rogers, P. The value of cooperation in resolving international river basin disputes. In Natural Resources Forum; Wiley Online Library: Hoboken, NJ, USA, 1993.

92. Bhaduri, A.; Barbier, E. Linking rivers in the Ganges-Brahmaputra River Basin: Exploring the transboundary effects. In Strategic Analyses of the National River Linking Project (NRLP) of India Series 2; International Water Management Institute: Colombo, Sri Lanka, 2008; p. 373.

93. Becker, N.E.; Easter, K.W. Water diversions in the great lakes basin analyzed in a game theory framework. Water Resour. Manag. 1995, 9, 221-242. [CrossRef]

94. Hardin, G. The tragedy of the commons. Science 1968, 162, 1243-1248. [PubMed]

95. Coase, R.H. The problem of social cost. J. Law Econ. 1960, 3, 1-44. [CrossRef]

96. Nigatu, G.; Dinar, A. Modeling Efficiency, Equity and Externality in the Eastern Nile River Basin; Water Science Policy Center. University of California: Riverside, CA, USA, 2011; Available online: http://wspc.ucr.edu/ working_papers/WSPC_WP_02_0611_Modeling (accessed on 6 May 2016).

97. Zeitouni, N.; Becker, N.; Shechter, M. Models of water market mechanisms and an illustrative application to the Middle East. Resour. Energy Econ. 1994, 16, 303-319. [CrossRef]

98. Zetland, D. All-in-Auctions for water. J. Environ. Manag. 2013, 115, 78-86. [CrossRef]

99. Bhaduri, A.; Barbier, E.B. International water transfer and sharing: The case of the Ganges River. Environ. Dev. Econ. 2008, 13, 29-51. [CrossRef]

100. Whittington, D.; Waterbury, J.; McClelland, E. Toward a new Nile waters agreement. In Water Quantity/Quality Management and Conflict Resolution, Institutions, Processes, and Economic Analyses; Preager: Westport, CT, USA, 1994; pp. 167-178.

101. Dinar, A.; Nigatu, G.S. Distributional considerations of international water resources under externality: The case of Ethiopia, Sudan and Egypt on the Blue Nile. Water Resour. Econ. 2013, 2, 1-16. [CrossRef]

102. Aytemiz, L. The Optimal Joint Provision of Water for Irrigation and Hydropower in the Euphrates River: The Case of Conflict between Turkey and Syria'. Ph.D. Thesis, Oklahoma State University, Stillwater, OK, USA, 2001. 
103. Fisher, F.M.; Arlosoroff, S.; Eckstein, Z.; Haddadin, M.; Hamati, S.G.; Huber-Lee, A.; Jarrar, A.; Jayyousi, A.; Shamir, U.; Wesseling, H. Optimal water management and conflict resolution: The Middle East Water Project. Water Resour. Res. 2002, 38, 25-1-25-17. [CrossRef]

104. Blatter, J.; Ingram, H. States, markets and beyond: Governance of transboundary water resources. Nat. Resour. J. 2000, 40, 439.

105. Sugden, R. Rational Choice: A Survey of Contributions from Economics and Philosophy. Econ. J. 1991, 101, 751-785. [CrossRef]

106. Vriend, N.J. Rational behavior and economic theory. J. Econ. Behav. Organ. 1996, 29, 263-285. [CrossRef]

107. Ramsey, F.P. The Foundations of Mathematics and Other Logical Essays; Routledge \& Kegan Paul: London, UK, 1931.

108. von Neumann, J.; Morgenstern, O. Theory of Games and Economic Behaviour; Princeton University Press: Princeton, NJ, USA, 1944.

109. Dixit, A.K. The Making of Economic Policy: A Transaction-Cost Perspective; The MIT Press: Cambridge, MA, USA, 1996.

110. Dixit, A.; Skeath, S.; Reiley, D. Games of Strategy; W. W. Norton \& Company: New York, NY, USA, 1999.

111. Cerdá, E. International Environmental Agreements and Game Theory. In Modern Mathematical Tools and Techniques in Capturing Complexity; Pardo, L., Balakrishnan, N., Gil, M.A., Eds.; Springer: Berlin/Heidelberg, Germany, 2011; pp. 287-300.

112. Axelrod, R.M. The Evolution of Cooperation; Basic Books, Inc.: New York, NY, USA, 1984.

113. Allison, G.; Zelikow, P. The Essence of Decision; Addison-Wisley Longman, Inc.: New York, NY, USA, 1971.

114. Ostrom, E.; Gardner, R.; Walker, J. Rule, Games, and Common-Pool Resources; The University of Michigan Press: Ann Arbor, MI, USA, 1994.

115. Aumann, R.J. Rationality and bounded rationality. Games Econ. Behav. 1997, 21, 2-14. [CrossRef]

116. Simon, H.A. A behavioral model of rational choice. Q. J. Econ. 1955, 69, 99-118. [CrossRef]

117. Dufournaud, C.M. On the mutually beneficial cooperative scheme: Dynamic change in the payoff matrix of international river basin schemes. Water Resour. Res. 1982, 18, 764-772. [CrossRef]

118. Hipel, K.; Kilgour, D.M.; Fang, L.; Li, K.W. Resolution of Water Conflicts between Canada and the United States; Paper submitted for the PCCP Project report; UNESCO: Paris, France, 2003.

119. Elimam, L.; Rheinheimer, D.; Connell, C.; Madani, K. An ancient struggle: A game theory approach to resolving the Nile conflict. In Proceeding of the 2008 World Environmental and Water Resources Congress, Honolulu, HI, USA, 12-16 May 2008; American Society of Civil Engineers: Reston, VA, USA, 2008.

120. Madani, K.; Rheinheimer, D.E.; Elimam, L.; Connell-Buck, C. A game theory approach to understanding the Nile River Basin conflict. In A Water Resource" Festschrift in Honor of Professor Lars Bengtsson, Division of Water Resources Engineering; Lund University: Lund, Sweden, 2011; pp. 97-114.

121. Wu, X.; Whittington, D. Incentive compatibility and conflict resolution in international river basins: A case study of the Nile Basin. Water Resour. Res. 2006, 42. [CrossRef]

122. Wu, X. Applying Game Theory to Water Conflicts in International River Basins: A Case Study of the Nile Basin; VDM Verlag Dr. Muller Akiengesellschaft: Saarbruken, Germany, 2009.

123. Dinar, A.; Wolf, A. Economic potential and political considerations of regional water trade: The Western Middle East example. Resour. Energy Econ. 1994, 16, 335-356. [CrossRef]

124. Dinar, A.; Wolf, A. International markets for water and the potential for regional cooperation: Economic and political perspectives in the western Middle East. Econ. Dev. Cult. Chang. 1994, 43, 43-66. [CrossRef]

125. Kucukmehmetoglu, M. A Game Theoretic Approach to Assess the Impacts of Major Investments on Transboundary Water Resources: The Case of the Euphrates and Tigris. Water Resour. Manag. 2009, 23, 3069-3099. [CrossRef]

126. Kucukmehmetoglu, M. Water Resources Allocation and Conflicts: The Case of the Euphrates and the Tigris; The Ohio State University: Columbus, OH, USA, 2002.

127. Atwi, M.; Chóliz, J.S. A negotiated solution for the Jordan Basin. J. Oper. Res. Soc. 2011, 62, 81-91. [CrossRef]

128. Kilgour, M.D.; Dinar, A. Flexible Water Sharing within an International River Basin. Environ. Resour. Econ. 2001, 18, 43-60. [CrossRef]

129. Fernandez, L. Trade's dynamic solutions to transboundary pollution. J. Environ. Econ. Manag. 2002, 43, 386-411. [CrossRef] 
130. Fernandez, L. Wastewater pollution abatement across an international border. Environ. Dev. Econ. 2009, 14, 67-88. [CrossRef]

131. Frisvold, G.B.; Caswell, M.F. Transboundary water management Game-theoretic lessons for projects on the US-Mexico border. Agric. Econ. 2000, 24, 101-111.

132. Supalla, R.J.; Klaus, B.; Yeboah, O.B.; Bruins, R.J.F. Game theory approach to deciding who will supply instream flow water. J. Am. Water Resour. Assoc. 2002, 38, 959-966. [CrossRef]

133. Bhaduri, A.; Manna, U.; Barbier, E.; Liebe, J. Climate change and cooperation in transboundary water sharing: An application of stochastic Stackelberg differential games in Volta river basin. Nat. Resour. Model. 2011, 24, 409-444. [CrossRef]

134. Madani, K.; Hipel, K.W. Non-Cooperative Stability Definitions for Strategic Analysis of Generic Water Resources Conflicts. Water Resour. Manag. 2011, 25, 1949-1977. [CrossRef]

135. Sheikhmohammady, M.; Madani, K. Sharing a multi-national resource through bankruptcy procedures. In World Environmental and Water Resources Congress; ASCE: Reston, VA, USA, 2008.

136. Ostorm, E. Governing the Commons: The Evolution of Institutions for Collective Actions; Cambridge University Press: Cambridge, UK, 1990.

137. Ostrom, E. Doing institutional analysis. In Handbook of New Institutional Economics; Springer: Heidelberg, Germany, 2008; pp. 819-848.

138. North, D.C. The new institutional economics and third world development. In The New Institutional Economics and Third World Development; Harriss, J., Hunter, J., Lewis, C.M., Eds.; Routledge: London, UK, 1997; pp. 17-26.

139. Simon, H.A. Administrative Behavior; Macmillan: New York, NY, USA, 1947.

140. Simon, H.A. Models of Man: Social and Rational; John Wiley \& Sons: New York, NY, USA, 1957.

141. Simon, H.A. Rational decision making in Business organisation. Am. Econ. Rev. 1979, 69, 493-513.

142. North, D.C. Insttitutions, Institutional Change and Economic Performance; Cambridge University Press: New York, NY, USA, 1990.

143. North, D.C. Institutions and the performance of economics over time. In Handbook of New Institutional Economics; Ménard, C., Shirley, M.M., Eds.; Springer: Heidelberg, Germany, 2008; pp. 21-30.

144. Ménard, C.; Shirley, M.M. Introduction. In Handbook of New Insititutional Economics; Ménard, C., Shirley, M.M., Eds.; Springer: Heidelberg, Germany, 2008; pp. 1-18.

145. Scott, R.W. Institutions and Organisations; SAGE Publications Ltd.: London, UK, 1995.

146. Zucker, L.G. The role of institutionalisation in cultural persistence. In The New Insititutionalism in Organisational Analysis; Powell, W.W., Di Maggio, P.J., Eds.; The University of Chicago Press: Chicago, IL, USA, 1991; pp. 83-107.

147. Mehta, L.; Leach, M.; Scoones, L. Exploring Understandings of Institutions and Uncertainty: New Directions in Natural Resource Management; Institute of Development Studies: Falmer, UK, 1999.

148. Crawford, S.E.S.; Ostrom, E. A Grammar of Institutions. Am. Political Sci. Rev. 1995, 89, 582-600. [CrossRef]

149. Susskind, L.; Islam, S. Water diplomacy: Creating value and building trust in transboundary water negotiations. Sci. Dipl. 2012, 1,1-7.

150. Tayia, A. The Role of Institucional Change in the Management of Common-Pool Resources: The Nile Basin; Universidad Complutense de Madrid: Madrid, Spain, 2015.

151. Tayia, A.; Madani, K. Resilient Transboundary Water Management Institutions. In World Environmental and Water Resources Congress 2017; ASCE: Reston, VA, USA, 2017.

152. Phillips, D.; Daoudy, M.; McCaffrey, S. Trans-Boundary Water Cooperation as a Tool for Conflict Prevention and Broader Benefit-Sharing; Ministry for Foreign Affairs: Stockholm, Sweden, 2006.

153. Sadoff, C.W.; Grey, D. Cooperation on international rivers: A continuum for securing and sharing benefits. Water Int. 2005, 30, 420-427. [CrossRef]

154. Daoudy, M. Getting beyond the environment-conflict trap: Benefit sharing in international river basins. In Transboundary Water Management; Routledge: Abingdon, UK, 2013; pp. 56-68.

155. Tawfik, R. The Grand Ethiopian Renaissance Dam: A benefit-sharing project in the Eastern Nile? Water Int. 2016, 41, 574-592. [CrossRef]

156. Allan, J.A.T. Fortunately there are substitutes for water otherwise our hydro-political futures would be impossible. Prior. Water Resour. Alloc. Manag. 1993, 13, 26. 
157. Allan, J.A.T. Overall perspectives on countries and regions. In Water in the Arab World: Perspectives and Prognoses; Rogers, P., Lydon, P., Eds.; Harvard University Press: Cambridge, MA, USA, 1994; pp. 65-100.

158. Allan, J.A.T. 'Virtual Water': A Long Term Solution for Water Short Middle Eastern Economies? School of Oriental and African Studies, University of London: London, UK, 1997.

159. Allan, J.A.T. Middle Eastern hydropolitics: Interpreting constructed knowledge. Geopolitics 1998, 3, $125-132$. [CrossRef]

160. Allan, J.A.T. Water stress and global mitigation: Water food and trade. Arid Lands Newsl. 1999, 45. Available online: https://cals.arizona.edu/OALS/ALN/aln45/allan.html (accessed on 18 November 2016).

161. Allan, J.A.T. IWRM/IWRAM: A new sanctioned discourse. Occas. Pap. 2003, 50, 1-27.

162. Mirumachi, N.; Allan, J.A. Revisiting transboundary water governance: Power, conflict cooperation and the political economy. In Proceedings of the CAIWA International Conference on Adaptive and Integrated Water Management: Coping with Scarcity, Basel, Switzerland, 12-15 November 2007.

163. Allan, T. Virtual Water: Tackling the Threat to Our Planet's most Precious Resource; IB Tauris: London, UK, 2011.

164. Hoekstra, A.Y.; Hung, P.Q. Virtual water trade. A Quantification of Virtual Water Flows between Nations in Relation to International Crop Trade; Value of Water Research Report Series No. 11; IHE Delft: Delf, The Netherlands, 2002.

165. Haddadin, M. Exogenous Water: A conduit to globalization of water resources. In Virtual Water Trade: Proceedings of the International Expert Meeting on Virtual Water Trade; Value of Water Research Report Series; IHE Delft: Delf, The Netherlands, 2003.

166. Zeitoun, M.; Allan, J.T.; Mohieldeen, Y. Virtual water 'flows' of the Nile Basin, 1998-2004: A first approximation and implications for water security. Glob. Environ. Chang. 2010, 20, 229-242. [CrossRef]

167. Tayia, A. Water Security in Egypt: Potential for and Constraints on Virtual-Water Decoupling in Achieving Food-Water Security. In Centre for Environmental Policy; Imperial College London: London, UK, 2019.

168. Zeitoun, M.; Allan, J.A.T. Virtual Water 'Flows' of the Nile Basin; FAO: Rome, Italy, 2007.

169. Allan, J.A.T. Nile Basin asymmetries: A closed fresh water resource, soil water potential, the political economy and Nile transboundary hydropolitics. In The Nile; Springer: Berlin/Heidelberg, Germany, 2009; pp. 749-770.

170. Allan, J.A.T. Hydro-peace in the Middle East: Why no water wars? A case study of the Jordan River Basin. SAIS Rev. 2002, 22, 255-272.

171. Allan, J.A.T. Water resources in semi-arid regions: Real deficits and economically invisible and politically silent solutions. In Hydropolitics in the Developing World: A Southern African Perspective; African Water Issues Research Unit, University of Pretoria: Pretoria, South Africa, 2002.

172. Elhance, A.P. Hydropolitics: Grounds for despair, reasons for hope. Int. Negot. 2000, 5, 201-222. [CrossRef]

173. Hussein, H.; Grandi, M. Dynamic political contexts and power asymmetries: The cases of the Blue Nile and the Yarmouk Rivers. Int. Environ. Agreem. Politics Law Econ. 2017, 17, 795-814. [CrossRef]

174. Hussein, H.; Menga, F.; Greco, F. Monitoring transboundary water cooperation in SDG 6.5. 2: How a critical hydropolitics approach can spot inequitable outcomes. Sustainability 2018, 10, 3640.

175. Meissner, R. A Definition of Water (Hydro-) Politics; Natural Resources and the Environment Research Area: Pretoria, South Africa, 2001.

176. Elhance, A.P. Hydropolitics in the Third World: Conflict and Cooperation in International River Basins; US Institute of Peace Press: Washington, DC, USA, 1999.

177. Warner, J.; Mirumachi, N.; Farnum, R.L.; Grandi, M.; Menga, F.; Zeitoun, M. Transboundary 'hydro-hegemony': 10 years later. Wiley Interdiscip. Rev. Water 2017, 4, e1242. [CrossRef]

178. Turton, A.R. Hydropolitics: The concept and its limitations. In Hydropolitics in the Developing World: A Southern African Perspective; African Water Issues Research Unit (AWIRU): Pretoria, South Africa, 2002; pp. 13-19.

179. Warner, J.F.; Zeitoun, M. International relations theory and water do mix: A response to Furlong's troubled waters, hydro-hegemony and international water relations. Political Geogr. 2008, 27, 802-810. [CrossRef]

180. Zeitoun, M.; Warner, J. Hydro-hegemony-A framework for analysis of trans-boundary water conflicts. Water Policy 2006, 8, 435-460. [CrossRef]

181. Cascão, A.E.; Zeitoun, M. Power, hegemony and critical hydropolitics. In Transboundary Water Management; Routledge: Abingdon, UK, 2013; pp. 40-55. 
182. Zeitoun, M.; Mirumachi, N.; Warner, J. Transboundary water interaction II: Soft power underlying conflict and cooperation. Int. Environ. Agreem. 2011, 11, 159-178. [CrossRef]

183. Zeitoun, M.; Talhami, M.; Eid-Sabbagh, K. The Influence of Narratives on Negotiations and Resolution of the Upper Jordan River Conflict. Int. Nogotiation 2013, 18, 293-322. [CrossRef]

184. Hussein, H. Whose 'reality'? Discourses and hydropolitics along the Yarmouk River. Contemp. Levant 2017, 2, 103-115. [CrossRef]

185. Zeitoun, M.; Mirumachi, N. Transboundary water interaction I: Reconsidering conflict and cooperation. Int. Environ. Agreem. Politics Law Econ. 2008, 8, 297. [CrossRef]

186. Zeitoun, M.; Cascão, A.E.; Warner, J.; Mirumachi, N.; Matthews, N.; Menga, F.; Farnum, R. Transboundary water interaction III: Contest and compliance. Int. Environ. Agreem. Politics Law Econ. 2017, 17, 271-294. [CrossRef]

187. Zeitoun, M.; Mirumachi, N.; Warner, J.; Kirkegaard, M.; Cascão, A. Analysis for water conflict transformation. Water Int. 2019, 1-20. [CrossRef]

188. Sneddon, C.; Fox, C. Rethinking transboundary waters: A critical hydropolitics of the Mekong basin. Political Geogr. 2006, 25, 181-202. [CrossRef]

189. Hussein, H. Lifting the veil: Unpacking the discourse of water scarcity in Jordan. Environ. Sci. Policy 2018, 89, 385-392. [CrossRef]

190. Tawfik, R. Changing Hydropolitical Relations in the Nile Basin: A Protracted Transition. Int. Spect. 2016, 51, 67-81. [CrossRef]

191. Tawfik, R. Revisiting Hydro-Hegemony from a Benefit-Sharing Perspective: The Case of the Grand Ethiopian Renaissance Dam; Discussion Paper; Deutsches Institut für Entwicklungspolitik: Bonn, Germany, 2015.

192. Tawfik, R. Reconsidering counter-hegemonic dam projects: The case of the Grand Ethiopian Renaissance Dam. Water Policy 2016, 18, 1033-1052. [CrossRef]

193. Middleton, C.; Allouche, J. Watershed or Powershed? Critical Hydropolitics, China and the 'Lancang-Mekong Cooperation Framework'. Int. Spect. 2016, 51, 100-117.

194. Hussein, H. The Guarani Aquifer System, highly present but not high profile: A hydropolitical analysis of transboundary groundwater governance. Environ. Sci. Policy 2018, 83, 54-62. [CrossRef]

195. Hussein, H. Yarmouk, Jordan, and Disi basins: Examining the impact of the discourse of water scarcity in Jordan on transboundary water governance. Mediterr. Politics 2019, 24, 269-289. [CrossRef]

196. da Silva, L.P.B.; Hussein, H. Production of scale in regional hydropolitics: An analysis of La Plata River Basin and the Guarani Aquifer System in South America. Geoforum 2019, 99, 42-53. [CrossRef]

197. Bruce, C.; Madani, K. Successful Collaborative Negotiation over Water Policy: Substance versus Process. J. Water Resour. Plan. Manag. 2015, 141, 04015009. [CrossRef]

198. Sheikhmohammady, M.; Madani, K. A descriptive model to analyze asymmetric multilateral negotiations. In Proceedings of the 2008 Universities Council on Water Resources Conference, Pittsburgh, PA, USA, 26-28 June 2008.

199. Browder, G. An analysis of the negotiations for the 1995 Mekong Agreement. Int. Negot. 2000, 5, $237-261$. [CrossRef]

200. Dinar, A.; Alemu, S. The process of negotiation over international water disputes: The case of the Nile Basin. Int. Negot. 2000, 5, 331-356. [CrossRef]

201. Haddadin, M.J. Negotiated resolution of the Jordan-Israel water conflict. Int. Negot. 2000, 5, $263-288$. [CrossRef]

202. Kibaroglu, A.; Ünver, I.O. An institutional framework for facilitating cooperation in the Euphrates-Tigris river basin. Int. Negot. 2000, 5, 311-330. [CrossRef]

203. Nishat, A.; Faisal, I.M. An assessment of the institutional mechanisms for water negotiations in the Ganges-Brahmaputra-Meghna system. Int. Negot. 2000, 5, 289-310. [CrossRef]

(C) 2019 by the author. Licensee MDPI, Basel, Switzerland. This article is an open access article distributed under the terms and conditions of the Creative Commons Attribution (CC BY) license (http://creativecommons.org/licenses/by/4.0/). 